\title{
Structural, functional, and sensorial properties of protein isolate produced from salmon, cod, and herring by-products
}

\author{
Mehdi Abdollahi $^{1} \cdot$ Ingrid Undeland ${ }^{1}$
}

Received: 8 May 2018 / Accepted: 19 June 2018 / Published online: 29 June 2018

(C) The Author(s) 2018

\begin{abstract}
Nutritional, structural, functional, and sensorial properties of protein isolate developed from salmon (Salmo salar), cod (Gadus morhua), and herring (Clupea harengus) by-products using the pH-shift method was studied. Function of the proteins in an emulsion system in terms of viscoelastic properties was also evaluated. Regardless of origin, the proteins showed satisfying nutritional value as reflected in their high essential amino acid content. The proteins contained significantly $(p<0.05)$ higher proportion of active sulfhydryl groups and surface hydrophobicity compared to whey and egg white protein reflecting conformational changes caused by the $\mathrm{pH}$-shift process. Solubility, emulsion, and foaming capacity of the proteins showed a trend similar to soy protein and dependent on their origin. Cod protein had better emulsion and foaming capacity than salmon and herring proteins which was in line with its high surface hydrophobicity and myosin heavy chain content. Emulsions developed from cod and salmon proteins showed substantially better viscoelastic properties, with higher stability and viscosity compared to herring protein emulsions. Cod protein scored low for sensorial attributes related to lipid oxidation while herring protein showed high levels of fishy and rancid flavor and odor. Altogether, results showed that the proteins from fish filleting by-products have potential to be used as food ingredients, but their application would be governed by their origin and sensorial properties.
\end{abstract}

Keywords Fish protein $\cdot$ Functional properties $\cdot$ By-products $\cdot$ Structural properties $\cdot$ Protein isolate

\section{Introduction}

The fish processing industry produces huge amounts of side streams including heads, backbones, tails, viscera, blood, and trimmings which normally form more than $50 \%$ of the fish weight (Shahidi 2006). Based on industrial activities, these by-products are currently mainly used as animal feed by processing into fish meal or silage or in some cases even wasted (Aspevik et al. 2016). Some of these by-products like the fish heads, backbones, tails, and trimmings can be good sources of high-value food-grade ingredients like fish protein. However, the complex nature of these materials related to having high levels of heme-proteins, enzymes, and lipid as well as

Mehdi Abdollahi

khozaghi@chalmers.se; abdollahi.mkh@gmail.com

1 Department of Biology and Biological Engineering-Food and Nutrition Science, Chalmers University of Technology, 412 96 Gothenburg, SE, Sweden difficulties in removing unwanted materials (e.g., bones, scales and connective tissues) have barricaded their successful market penetration (Abdollahi et al. 2016). These challenges have caused continuous research for finding novel alternative methods that can recover proteins from by-products, while retaining the protein functionality.

In this regard, acid and/or alkaline solubilization followed by isoelectric precipitation, also called the $\mathrm{pH}$-shift processing (Hultin et al., 2001), has been successfully recognized as a promising technique for direct protein recovery from unconventional complex aquatic raw materials, including gutted fish (Taskaya et al., 2009; Marmon and Undeland 2010) and seafood processing by-products (Chen and Jaczynski, 2007; Shaviklo et al. 2012). The process involves selectively extracting proteins from homogenized raw material using a high $(>10.5)$ or a low $(<3.5) \mathrm{pH}$ to solubilize the muscle proteins followed by centrifugation to separate the solubilized proteins from high and low density undissolved material. The solubilized proteins are then recovered using isoelectric precipitation (usually $\mathrm{pH}$ 5.5) and dewatered by centrifugation or filtration. The recovered protein isolate can be mixed with 
cryoprotectants and then frozen like surimi or minced fish or might be directly dried into a fish protein powder (FPP) for further utilization.

If the FPP be surimi of white muscle fish fillets, which have low fat and heme pigment content, an excellent source of high quality and concentrated fish protein can be provided, which can be easily added to a wide range of food products as a good source of easily digestible amino acids (Santana et al. 2012). As a low fat, high protein content ingredient, it also has potential to be used as a binder, dispersing agent, and emulsifier in various re-structured food products due to its strong interactions with other proteins and its good gelation capacity (Pires et al. 2009). However, in case of using fish processing byproducts for production of FPP, little is known on how functional and sensorial properties are affected by the complexity of the by-products. Pires et al. (2012) reported acceptable functional properties for freeze-dried protein isolate from Cape hake sawdust by alkaline-aid $\mathrm{pH}$-shift process but Shaviklo et al. (2012) found sensory attributes related to lipid oxidation in freeze-dried protein isolate of saithe cut-offs generated with the same process. In both studies, however, non-bony by-products from white muscle fish resources were used. However, to the best of our knowledge, there is no report considering the properties of FPPs produced from more complicated fish byproduct like heads and backbones using the $\mathrm{pH}$-shift method. Also, there is no a comprehensive report evaluating the effect of the fish species generating the by-products on the quality of the FPP developed using the pH-shift process; e.g., dark vs. white muscle fish and fatty fish vs. lean fish. Moreover, final application of the isolated proteins will be determined based on their functional properties like solubility, emulsion capacity, foaming capacity, and oil/water absorption. These properties depend on the physicochemical and structural properties of the proteins and directly contribute to the taste, texture, and consumer acceptance of food products. Thus, understanding the effects of fish origin and the protein isolation process on nutritional and functional properties of fish protein isolate from the by-products is of key importance, determining final application of the isolated protein.

Thus, the present study was aimed to evaluate nutritional, structural, functional, and sensorial properties of FPPs developed from protein isolates generated with the $\mathrm{pH}$-shift process from by-products of three different fish origins; salmon (Salmo salar), cod (Gadus morhua), and herring (Clupea harengus). In addition, properties of the developed FPPs were compared with dried soy, whey, and egg white albumin proteins to better understand potentials and limitations of the FPPs. An emulsion system was also developed from the three FPPs and their viscoelastic properties were studied.

\section{Materials and methods}

\section{Chemicals}

Sodium hydroxide, hydrochloric acid, trichloroacetic acid (TCA), and sodium chloride were provided by Scharlau (Scharlau Co., Spain). Sodium dodecyl sulphate (SDS), $\beta$ mercaptoethanol ( $\beta$-ME), glycerol, 5,5'-dithiobis(2nitrobenzoic acid) (DTNB), 8-Anilino-1-naphthalenesulfonic acid ammonium salt (ANS), and glutaraldehyde were purchased from Sigma-Aldrich Corp. (USA). Soy protein isolate (SPI), egg white protein (EWP, and whey protein isolate (WPI) were provided by Engelhardt co. (Gothenburg, Sweden).

\section{Fish sample preparation}

Fresh filleting by-product (head and tail on backbone) of cod (Gadus morhua) and salmon (Salmo salar) were provided by Fisk Idag Company (Gothenberg, Sweden). Herring (Clupea harengus) filleting by-product (head, backbone, and tail) were also provided by Swedish Pelagic Company. In the same day as processing, all fish by-products were fully covered with ice and were transported in the minimum of possible time. The samples were immediately minced using a table top meat mincer (C/E22 N, Minerva Omega group, Italy) equipped with a plate with $3 \mathrm{~mm}$ holes and pooled completely. Finally, the mince was frozen at $-80{ }^{\circ} \mathrm{C}$ in plastic zip-lock bags for further use.

\section{Protein isolation and protein powder development}

Minced by-products were subjected to $\mathrm{pH}$-shift processing following the main principle described by Undeland et al. (2002) but with some modifications. Minced sample (800 g) was homogenized with six volumes of cold distilled water for 2 min at speed 6 using a Polytron Homogenizer (IKA, Brazil). The time of homogenization was primarily optimized, and the homogenizer was moved during mixing in a way that the whole solution was uniformly homogenized to help uniform $\mathrm{pH}$ adjusted throughout the process. Then, the homogenate was adjusted to $\mathrm{pH} 11.5$ for cod and 12 for salmon and herring (based on a primary study on protein yield) using $2 \mathrm{M} \mathrm{NaOH}$, respectively. The $\mathrm{pH}$ was automatically adjusted with a titrator (907 Titrando, Metrohm AG, Zurich, Switzerland) in set pH mode with a maximum titration rate. The $\mathrm{pH}$ was monitored with a calibrated Hamilton double pore electrode (Bonaduz, Switzerland) coupled to the titrator. The $\mathrm{pH}$-adjusted slurry was allowed to stand in ice for $10 \mathrm{~min}$ and then centrifuged at $8,500 \mathrm{~g}$ in a precooled $\left(4^{\circ} \mathrm{C}\right)$ Thermo Scientific Sorvall LYNX Superspeed Centrifuge (Thermo Fisher Scientific, Waltham, USA) for 20 min followed by recovery of the soluble protein. The soluble protein was then adjusted to $\mathrm{pH} 5.5$ as 
described above using the titrator with 10 min holding time at $\mathrm{pH} 5.5$ on ice. A second centrifugation step at $8,500 \times \mathrm{g}\left(4^{\circ} \mathrm{C}\right.$, $20 \mathrm{~min}$ ) was then used to dewater the precipitated proteins. Recovered protein isolates were collected, and their $\mathrm{pH}$ was adjusted under cold condition $\left(<4{ }^{\circ} \mathrm{C}\right)$ to 7.0 using cold $2 \mathrm{~N} \mathrm{NaOH}$. The protein isolates were then lyophilized using a freeze-drier at $-56^{\circ} \mathrm{C}$ for 5 days. Then, the samples were powdered using a coffee grinder and about $100 \mathrm{~g}$ of each type of protein powder was obtained. The powders were stored at $-80{ }^{\circ} \mathrm{C}$ until further analysis.

\section{Characterization of protein powders}

\section{Amino acid analysis}

Amino acid composition of the protein powders was analyzed based on the method explained by Özcan and Șenyuva (2006) with some modifications. Six milligrams of freeze-dried powders was mixed with $4 \mathrm{ml}$ of $6 \mathrm{~N} \mathrm{HCl}$ and hydrolyzed at $110{ }^{\circ} \mathrm{C}$ for $24 \mathrm{~h}$. Aliquots of the hydrolyzed samples were automatically injected to LC/MS (Agilent 1100 HPLC, Waldbron, Germany) with a Phenomenex column (C18 (2) $250 \mu \mathrm{m} \times 4.6 \mu \mathrm{m} \times 3 \mu \mathrm{m}$ ), coupled to an Agilent 6120 quadrupole in the SIM positive mode (Agilent Technologies, Germany) and compared against standard amino acids which were analyzed before. Sample preparation and injection were conducted in two replicates, respectively. With this method, tryptophan and cysteine were not recovered.

\section{Active and total sulfhydryl groups measurement}

Active and total sulfhydryl groups content of the proteins were measured as explained by Gong et al. (2015). Initially, $180 \mathrm{mg}$ of protein was added to $30 \mathrm{~mL}$ Triseglycine buffer (0.086 M Tris, 0.09 M glycine, 4 mM EDTA, pH 8.0) containing $8 \mathrm{M}$ urea and stirred for $30 \mathrm{~min}$ at room temperature. Then, the solution was centrifuged at $10,000 \mathrm{~g}$ for $10 \mathrm{~min}$ and the supernatant was collected. To measure the content of active sulfhydryl groups content, $4 \mathrm{~mL}$ of the diluted supernatant was added to $160 \mu \mathrm{L}$ DTNB (4 $\mathrm{mg} / \mathrm{mL}$ in the same buffer) and incubated for $15 \mathrm{~min}$. The absorbance of the mixture was read at $412 \mathrm{~nm}$ using a spectrophotometer (Cary $60 \mathrm{UV}$-vis, Agilent technologies, Santa Clara, USA). The reagent (buffer + DTNB) was used as control, and the active sulfhydryl groups content was calculated using Eq. (1).

Active sulfhydryl groups $(\mu \mathrm{mol} / \mathrm{g})$

$$
=\frac{73.53 \times \mathrm{Abs} \text { at } 412 \mathrm{~nm}}{\text { Sample concentration }\left(\frac{\mathrm{mg}}{\mathrm{ml}}\right)}
$$

where, Abs at 412 is the absorbance at $412 \mathrm{~nm}$.
To measure total sulfhydryl group content, $8 \mu \mathrm{L}$ of $\beta$ ME was mixed with $4 \mathrm{~mL}$ of the supernatant. After storage at $25^{\circ} \mathrm{C}$ for $2 \mathrm{~h}, 10 \mathrm{~mL}$ of $12 \%$ trichloroacetic acid (TCA) was added and the mixture was stored $\left(1 \mathrm{~h}\right.$ at $\left.25^{\circ} \mathrm{C}\right)$ again. The sample was then centrifuged at $10,000 \times \mathrm{g}$ for $10 \mathrm{~min}$ and the pellet was rinsed with $5 \mathrm{ml}$ of TCA (12\%). The washing was repeated for three more times. Finally, the precipitate was dissolved in $6 \mathrm{~mL}$ of Tris-Glycine buffer, and $4 \mathrm{ml}$ of the diluted solution was mixed with $160 \mu \mathrm{L}$ DTNB reagent $(4 \mathrm{mg} / \mathrm{mL})$, and its absorbance was determined at $412 \mathrm{~nm}$. The above mixture without protein was used as control. Total sulfhydryl group content was calculated using the same equation used for active sulfhydryl groups content.

\section{Surface hydrophobicity analysis}

Surface hydrophobicity of the samples was measured according the method explained by Timilsena et al. (2016). The protein solution $(1 \mathrm{mg} / \mathrm{mL})$ was prepared in phosphate buffer (0.01 M, pH 7.0) and then centrifuged at $10,000 \mathrm{~g}$ for $20 \mathrm{~min}$ to remove any insoluble matter. The protein content of the fully dissolved fraction was determined, and protein dispersions with concentrations of $0.01-0.2 \%(w / v)$ were prepared by serially diluting with phosphate buffer $(0.01 \mathrm{M}, \mathrm{pH} 7.0)$. Then, $4 \mathrm{ml}$ of each diluted sample was mixed with $20 \mu \mathrm{l}$ of $8 \mathrm{mM}$ ANS solution (solubilized in the same buffer). After $15 \mathrm{~min}$ incubation in darkness, the fluorescent intensity of the mixed solutions was determined using excitation and emission wavelengths of 374 and $485 \mathrm{~nm}$, respectively. Fluorescent intensity of ANS alone and diluted protein solutions without the probe were also determined and were subtracted from the intensity of the sample. The calculated net fluorescent intensity of the proteins was then plotted against their protein content. The initial slope of the plot was considered as an index of average protein surface hydrophobicity.

\section{Color measurement}

Protein powders were subjected to color measurement with a colorimeter (CR-400, Konica Minolta Sensing, Japan) as explained by Yin et al. (2011). The color was measured in the CIE $L^{*} a^{*} b^{*}$ colour space by holding a probe directly against the bottom of a flat polystyrene plate containing protein samples. Five measurements of $L^{*}, a *$, and $b^{*}$ were taken at different locations of the plates. Whiteness was also calculated according to formula (2):

Whiteness $=100-\sqrt{(100-L)^{2}+a^{2}+b^{2}}$ 


\section{Bulk density measurement}

Bulk density of the protein powders was measured by filling a pre-weighed $10 \mathrm{~mL}$ graduated cylinder up to $10 \mathrm{~mL}$ mark with gentle tapping. The weight of the cylinder after filling was determined and used to calculate protein bulk density as $\mathrm{g} / \mathrm{mL}$.

\section{Protein water solubility}

To evaluate the effect of $\mathrm{pH}$ on the solubility of the proteins in water, $1 \mathrm{~g}$ of each protein powder was dissolved in $40 \mathrm{ml}$ distilled water, and its $\mathrm{pH}$ was adjusted to the range of 2-12 using $1 \mathrm{~N} \mathrm{HCl}$ or $\mathrm{NaOH}$ solutions. Thereafter, the solutions were centrifuged at $15,000 \times \mathrm{g}$ for $30 \mathrm{~min}$ at $4{ }^{\circ} \mathrm{C}$. Protein content of the supernatant was subsequently determined using a modified version of the Lowry method (Markwell et al. 1978), and relative solubility of the proteins was calculated based on the solubility at $\mathrm{pH}$ giving maximum solubility.

\section{Emulsion activity index and stability}

Emulsion activity index (EAI) and emulsion stability of the protein powders were measured according the method explained by Ogunwolu et al. (2009). Initially, $300 \mathrm{mg}$ of proteins was dispersed in $30 \mathrm{ml}$ distilled water, and its $\mathrm{pH}$ was adjusted to $3,5,7,9$, and 11 . Oil in water emulsion was then prepared by mixing the protein solution with $10 \mathrm{ml}$ of sunflower vegetable oil followed by homogenization at speed of $20,000 \times g$ for $1 \mathrm{~min}$. Then, $50 \mu \mathrm{l}$ of the emulsion in the bottom of the container was immediately and after $10 \mathrm{~min}$ pipetted into $5 \mathrm{ml}$ of $1 \% \mathrm{SDS}$ solution and vortexed for $20 \mathrm{~s}$. Absorbance of the solution was determined at $500 \mathrm{~nm}$ using spectrophotometer and the EAI and emulsion stability index (ESI) values were calculated using Eqs. (3) and (4), respectively.

Emulsion activity index $\left(\mathrm{m}^{2} / \mathrm{g}\right)=\frac{2 \times 2.303 \times A_{0} \times \mathrm{DF}}{C \times \varphi \times \theta \times 10000}(3)$

where $A_{0}=$ measured absorbance at $500 \mathrm{~nm}$; DF $=$ dilution factor $=200 ; \theta=$ path length of the cuvette $=1 \mathrm{~cm} ; C=$ the initial concentration of protein $(\mathrm{g} / \mathrm{mL}) ; \varphi=$ the volume fraction of oil in the emulsion $=0.25$.

Emulsion stability index $(\min )=\frac{A_{10} \times \Delta t}{\Delta A}$

where $\mathrm{A}_{10}$ is the absorbance at $10 \mathrm{~min}$ after homogenisation; $\Delta t=10 \mathrm{~min}$; and $\Delta A=A_{0}-A_{10}$.

\section{Rheological analysis of emulsion containing fish proteins}

To prepare an oil-in-water emulsion system, $3 \mathrm{~g}$ of each fish protein powder was dispersed in $32 \mathrm{~g}$ distilled water with magnetic stirrer for $30 \mathrm{~min}$. Then, $65 \mathrm{~g}$ of sunflower oil was added to the dispersion, and emulsification was conducted with an IKA-polytron homogenizer at 14,000 rpm for $5 \mathrm{~min}$ as previously reported by Tomé et al. (2014). The emulsions were sealed and stored for $24 \mathrm{~h}$ at $4{ }^{\circ} \mathrm{C}$ before color and rheological analysis.

Dynamic viscoelastic properties of the emulsions were evaluated using parallel-plate geometry $(25 \mathrm{~mm}$ plate diameter and $1 \mathrm{~mm}$ plate gap) mounted on a dynamic rheometer (Paar Physica Rheometer MCR 300, Anton Paar GmbH, Austria), operated in an oscillating and steady state mode at $20{ }^{\circ} \mathrm{C}$ using $0.5 \mathrm{~g}$ of emulsion samples. Frequency sweep test was conducted from 0.06283 to $628 \mathrm{rad} / \mathrm{s}$ at a constant shear stress within the linear viscoelastic region of each emulsion. Oscillation sweep test was done from 0.1 to $1000 \mathrm{~Pa}$ at a constant frequency $(6.283 \mathrm{rad} / \mathrm{s})$ within the linear viscoelastic region of each emulsion. Steady-state flow test was conducted by measuring viscosity during logarithmic increasing shear stress from 0.1 to $1000 \mathrm{~Pa}$ and viscosity was plotted versus shear rate. Carreau model (5) was used for analysis of the flow results:

$\eta=\frac{\eta_{0}}{\left[1+\left(\frac{\gamma}{\gamma^{c}}\right)^{2}\right]^{s}}$

where $\eta_{0}$ is the zero-shear rate limiting-viscosity, $\gamma^{\mathrm{c}}$ is the critical shear rate for the onset of the shear-thinning behavior and $s$ is a parameter related to the slope of the region.

\section{Foaming capacity and stability}

To measure foaming capacity and stability of the proteins, $250 \mathrm{mg}$ of each protein powder was dispersed in $25 \mathrm{ml}$ of distilled water ( $\mathrm{V}$-initial), and its $\mathrm{pH}$ was adjusted to 3, 5, 7, 9 , and 11. The dispersion was then homogenized using a Polytron homogenizer for $2 \mathrm{~min}$ at $10,000 \mathrm{rpm}$. The volume of the formed foam immediately after homogenization $\left(V_{1}\right)$ and after $60 \mathrm{~min}\left(V_{60}\right)$ was measured, and foaming capacity and foaming stability were calculated using Eqs. (6) and (7), respectively.

Foaming capacity $(\%)=\frac{V_{1}-\mathrm{V}_{\text {initial }}}{\mathrm{V}_{\text {initial }}} \times 100$

Foaming stability $(\%)==\frac{V_{60}-V_{\text {initial }}}{V_{\text {initial }}} \times 100$

\section{FTIR}

Fourier transform infrared (FT-IR) spectroscopic analysis of the protein samples was carried out according the method explained by Abdollahi et al. (2017). FT-IR spectra were obtained by placing fish protein and reference samples onto the 
crystal cell of a Nicolet 6700 spectrophotometer (Thermo Scientific, MA, USA) and scanning from 4,000 to $400 \mathrm{~cm}^{-1}$ at data acquisition rate of $4 \mathrm{~cm}^{-1}$ per point. All spectra were recorded at ambient temperature $\left(25^{\circ} \mathrm{C}\right)$ and 16 times scanning.

\section{Sodium dodecyl sulfate-polyacrylamide gel electrophoresis (SDS-PAGE)}

The polypeptide pattern of the fish proteins, their initial raw material, and the commercial reference proteins were investigated using SDS-PAGE according to the method of Laemmli (1970). Initially, $27 \mathrm{ml}$ of 5\% SDS solution was added to $3 \mathrm{~g}$ of each protein and homogenized using an Ultatorax at speed 3 for 2 min and heated at $85{ }^{\circ} \mathrm{C}$ for $1 \mathrm{~h}$. After cooling, the dissolved samples were centrifuged at 5,000 $\times \mathrm{g}$ for $20 \mathrm{~min}$ to remove undissolved residuals. The supernatant was mixed with an equal amount of Laemmli buffer (Bio-Rad, USA) containing 5\% $\beta$-mercaptoethanol and then boiled for $5 \mathrm{~min}$. Ten microliters of ladder (Prestained dual color standard, 10 $250 \mathrm{kDa}$, Bio-Rad, USA) and $15 \mu \mathrm{g}$ of protein from each sample were loaded onto a precast mini linear gels 4-20\% (Bio-Rad, USA). Electrophoresis was conducted at a constant voltage of $205 \mathrm{~V}$, using a Mini Protein II unit (Bio-Rad, USA). After separation, $0.02 \%(w / v)$ Coomassie Brilliant Blue R-250 in 50\% $(v / v)$ methanol and $7.5 \%(v / v)$ acetic acid was used for staining, and destaining was conducted with $50 \%$ methanol $(v /$ $v)$ and $7.5 \%(v / v)$ acetic acid for $1 \mathrm{~h}$. Finally, the gel was scanned in a GS-800 Calibrated Densitometer (Bio-Rad, USA).

\section{Sensory analysis}

Quantitative descriptive analysis (QDA) method was used to evaluate sensorial attributes of the three FPPs and soy protein powders in the form of a $1 \%$ solution $(1 \mathrm{~g}$ protein powder in $100 \mathrm{ml}$ distilled water) as explained by Shaviklo et al. (2012). Protein solutions were prepared in Erlenmeyer flasks with screw caps $1 \mathrm{~h}$ before analysis and stored cold. Six skilled panelist from Engelhardt Company (Gothenburg, Sweden) were initially trained and then asked to evaluate odor and flavor of the protein solutions in duplicate. Samples were coded with three-digit random codes and were evaluated based on an unstructured scale $(0$ $100 \%$ ). Samples were randomly served to the panelist on a tray in individual booths, and they were asked to evaluate intensity of the attributes by smelling or tasting the solutions in terms of odor (dried fish, rancidity, TMA, fish oil) and flavor (dried fish, rancidity, fish oil, sweetness, bitterness, seaweed, TMA, and off-flavor). To clean and neutralize palate, water was provided for the panelists.

\section{Statistical analysis}

All experiments in this research study were carried out in Completely Randomized Design Test, and one-way analysis of variance (ANOVA) and Duncan's multiple range test were used to determine the significant differences between the variables. Differences with a probability value of $<0.05$ were considered significant and all data were reported in the form of mean \pm SD. All experiments were run in triplicate $(n=3)$, except the mechanical properties, which was run in five replicates.

\section{Results and discussions}

\section{Amino acid composition}

As can be seen in Table 1, FPPs of the three species had significantly $(p<0.05)$ higher total amounts of essential amino acid (EAA) per g protein isolate compared to their initial raw materials. This result can be related to the successful removal of collagenous impurities like the bone and skin, which contain high amount of non-essential amino acids including glycine and proline, during the $\mathrm{pH}$-shift processing and concentration of the remained amino acids. However, salmon protein powder contained lower amount of EAA compared with cod and herring protein powders. In addition, all FPP's had considerably lower amount of glycine and proline compared with their original raw materials. Higher amount of EAA was also reported in $\mathrm{pH}$-shift produced protein isolates of rainbow trout (Y-C Chen et al. 2007) compared to their original raw material, i.e., gutted whole herring and trout byproducts.

All EAA found in the FPPs were well above the recommended requirement for adult based on WHO/FDA (WHO/ FAO/UNU 2007). However, methionine, histidine, and phenylalanine did not meet the infant recommended intakes which are higher than for adults. These results show higher nutritional value of the developed FPPs in this study compared to previously reported data for protein powder and isolates developed from hake cut-offs (Pires et al. 2012) and trout by-products (Y-C Chen et al. 2007) which only met the infant recommended intakes in their lysine and threonine content. Nutritional value in terms of total EAA was also higher in this study compared to that by (Sathivel et al. 2004) comprising protein powders developed by heat processing of arrowtooth flounder and herring.

The most abundant non-essential amino acid in the FPPs were glutamic acid and aspartic acid and when compared with the reference proteins, total amounts of EAA of the FPPs were higher than for SPI and almost similar to EWP and WPI. The content of lysine in FPPs, which is a very important EAA, was 91-101 mg/g which was higher than SPI (72 mg/g) and EWP 
Table 1 Amino acid composition of fish filleting by-product, FPPs, and reference proteins.

\begin{tabular}{|c|c|c|c|c|c|c|c|c|c|c|}
\hline \multirow[t]{2}{*}{ Amino acid } & \multicolumn{3}{|c|}{ By-product (mg/g dw) } & \multicolumn{6}{|c|}{ Protein powders (mg/g dw) } & \multirow{2}{*}{$\begin{array}{l}\text { FAO/WHO } \\
\text { Adult (infant) } \\
\text { (mg/g protein) }\end{array}$} \\
\hline & Salmon & Cod & Herring & Salmon & Cod & Herring & Soy & Egg & Whey & \\
\hline Glycine & $115.1 \pm 3.1$ & $110.4 \pm 2.1$ & $76.8 \pm 2.7$ & $51.6 \pm 3.1$ & $49.4 \pm 0.9$ & $47.9 \pm 0.9$ & $48.6 \pm 1.1$ & $38.9 \pm 1.6$ & $18.1 \pm 1.3$ & \\
\hline Alanine & $65.8 \pm 3.4$ & $64.1 \pm 2.0$ & $61.7 \pm 0.9$ & $62.5 \pm 3.4$ & $63.5 \pm 1.1$ & $64.6 \pm 0.6$ & $43.6 \pm 0.5$ & $56.2 \pm 0.7$ & $49.5 \pm 1.2$ & \\
\hline Serine & $44.3 \pm 1.7$ & $56.3 \pm 0.5$ & $48.1 \pm 0.6$ & $43.8 \pm 1.7$ & $45.5 \pm 0.7$ & $42.8 \pm 0.1$ & $52.0 \pm 0.6$ & $70.8 \pm 1.1$ & $50.0 \pm 0.2$ & \\
\hline Proline & $61.6 \pm 1.3$ & $64.6 \pm 4.3$ & $53.4 \pm 2.2$ & $29.1 \pm 1.3$ & $28.1 \pm 0.3$ & $34.2 \pm 0.0$ & $48.3 \pm 0.3$ & $29.0 \pm 0.7$ & $58.9 \pm 0.5$ & \\
\hline Valine* & $44.3 \pm 2.1$ & $44.1 \pm 1.2$ & $52.8 \pm 2.0$ & $62.2 \pm 2.1$ & $56.8 \pm 1.8$ & $63.8 \pm 0.2$ & $51.1 \pm 0.3$ & $71.2 \pm 2.1$ & $61.2 \pm 0.8$ & $39(55)$ \\
\hline Threonine* & $49.1 \pm 1.2$ & $46.4 \pm 0.3$ & $48.6 \pm 0.0$ & $52.5 \pm 1.2$ & $46.7 \pm 0.6$ & $48.8 \pm 0.1$ & $41.1 \pm 0.1$ & $49.2 \pm 0.7$ & $76.7 \pm 1.6$ & $23(31)$ \\
\hline Isoleucine* & $39.1 \pm 0.9$ & $39.7 \pm 1.1$ & $45.6 \pm 2.2$ & $53.3 \pm 0.9$ & $53.6 \pm 0.3$ & $54.3 \pm 0.3$ & $51.5 \pm 1.1$ & $57.2 \pm 1.1$ & $71.3 \pm 0.4$ & $30(32)$ \\
\hline Leucine* & $70.8 \pm 2.1$ & $74.1 \pm 2.3$ & $82.7 \pm 0.6$ & $96.4 \pm 2.1$ & $100.4 \pm 0.8$ & $101.9 \pm 0.6$ & $91.5 \pm 0.9$ & $95.0 \pm 2.1$ & $114.9 \pm 2.1$ & $59(66)$ \\
\hline Aspartic acid & $94.8 \pm 3.1$ & $99.8 \pm 0.1$ & $107.0 \pm 3.5$ & $99.0 \pm 3.1$ & $100.9 \pm 0.1$ & $105.8 \pm 1.5$ & $119.5 \pm 1.1$ & $104.7 \pm 2.3$ & $110.3 \pm 1.5$ & \\
\hline Lysine* & $80.4 \pm 1.2$ & $84.1 \pm 0.3$ & $88.3 \pm 0.4$ & $101.5 \pm 1.2$ & $101.4 \pm 0.3$ & $91.9 \pm 0.5$ & $72.9 \pm 0.2$ & $81.2 \pm 0.7$ & $109.9 \pm 3.1$ & $45(57)$ \\
\hline Glutamic acid & $136.1 \pm 3.6$ & $141.4 \pm 5.5$ & $149.5 \pm 3.2$ & $132.1 \pm 3.6$ & $144.5 \pm 2.5$ & $139.5 \pm 1.0$ & $185.9 \pm 4.1$ & $132.5 \pm 1.1$ & $179.5 \pm 2.1$ & \\
\hline Methionine* & $28.1 \pm 1.1$ & $29.7 \pm 0.8$ & $35.2 \pm 2.7$ & $35.4 \pm 1.1$ & $37.3 \pm 0.6$ & $36.9 \pm 0.2$ & $13.0 \pm 0.0$ & $42.2 \pm 0.2$ & $23.0 \pm 0.1$ & $17(42)$ \\
\hline Histidine* & $13.0 \pm 1.2$ & $10.4 \pm 1.2$ & $15.8 \pm 0.6$ & $24.6 \pm 1.2$ & $21.0 \pm 0.2$ & $23.7 \pm 0.4$ & $23.2 \pm 0.1$ & $16.8 \pm 0.1$ & $9.2 \pm 0.2$ & $15(20)$ \\
\hline Phenylalanine* & $42.7 \pm 0.1$ & $40.3 \pm 1.8$ & $47.7 \pm 1.1$ & $47.7 \pm 1.1$ & $47.6 \pm 0.2$ & $49.1 \pm 0.3$ & $59.8 \pm 0.4$ & $70.3 \pm 0.4$ & $32.6 \pm 0.2$ & $19(72)$ \\
\hline Arginine & $68.9 \pm 0.5$ & $69.4 \pm 0.9$ & $61.7 \pm 0.3$ & $55.7 \pm 1.5$ & $57.7 \pm 0.5$ & $55.1 \pm 0.5$ & $66.5 \pm 0.6$ & $49.7 \pm 0.5$ & $15.1 \pm 0.0$ & \\
\hline Tyrosine & $23.1 \pm 0.4$ & $25.5 \pm 0.4$ & $25.2 \pm 0.7$ & $40.0 \pm 0.4$ & $41.2 \pm 0.1$ & $41.0 \pm 0.1$ & $36.2 \pm 0.1$ & $36.2 \pm 0.5$ & $23.4 \pm 0.1$ & \\
\hline EAA & 473.8 & 465.1 & 470.7 & 404.4 & 483.4 & 499.2 & 371.9 & 395.5 & 414.5 & \\
\hline NEAA & 605.9 & 605.6 & 586.0 & 524.8 & 531.0 & 525.4 & 600.9 & 518.2 & 505.0 & \\
\hline EAA/AA & 0.38 & 0.40 & 0.41 & 0.47 & 0.47 & 0.47 & 0.40 & 0.48 & 0.50 & \\
\hline
\end{tabular}

$E A A$ total essential amino acid, $N E A A$ total non-essential amino acid, $A A$ total amino acid

*Shows essential amino acids

$(81 \mathrm{mg} / \mathrm{g}$ ) (which could help to make up for the lack of lysine in cereal foods (Zhong et al. 2016). )

\section{Active and total sulfhydryl groups measurement}

Sulfhydryl groups and disulfide bonds play important roles in some of the functional properties of proteins. As can be seen in Fig. 1a, the highest amount of total sulfhydryl groups was measured in WPI $(114.3 \mu \mathrm{mol} / \mathrm{g})$ and EWP $(105.7 \mu \mathrm{mol} / \mathrm{g})$ while FPPs had significantly lower amount of total sulfhydryl groups $(p<0.05)$. Minimum total sulfhydryl group content was measured in herring protein powder $(32 \mu \mathrm{mol} / \mathrm{g})$. These results may reflect the difference in the amino acid composition of the proteins from different origins having different amount of amino acids containing sulfur groups including methionine. On the other hand, FPPs showed considerably higher ratio of active sulfhydryl groups to total sulfhydryls. This means that a large part of the sulfhydryl groups of fish proteins are exposed, while in SPI, WPI, and EGA most of the sulfhydryl groups were in the form of disulfide bonds. Sulfurcontaining amino acids, especially methionine, are among of the most hydrophobic amino acids and are almost always found in the interior of protein. This high ratio of active sulfhydryl groups may suggest that conformational changes in the FPPs occurred during the pH-shift solubilization, precipitation, and/or freeze drying. It has been also previously reported that extreme $\mathrm{pHs}$ used during $\mathrm{pH}$-shift processing of fish proteins can cause unfolding of proteins causing exposure of buried sulfhydryl groups (Abdollahi et al. 2017). Further, it was reported that conformational changes and protein denaturation caused by high pressure and freeze-thaw cycles increased active sulfhydryl group content of walnut protein isolate (Qin et al. 2013) and SPI (Zhao et al. 2015), respectively.

\section{Surface hydrophobicity}

Among the FPPs, the one from herring showed the highest surface hydrophobicity followed by cod protein powder, while surface hydrophobicity of salmon protein powder was significantly lower than that for herring and cod protein powders $(p<0.05)$ (Fig. 1b). The lower surface hydrophobicity observed in the cod protein powder compared to herring might be related to the lower amount of conformational changes and thereby less exposure of internal hydrophobic side chains (Gong et al. 2015) caused by less extreme solubilization $\mathrm{pH}(\mathrm{pH}$ 11.5) used for this species compared to herring ( $\mathrm{pH}$ 12). Since both herring and salmon proteins were recovered using the same solubilization $\mathrm{pH}(12)$, the lower surface hydrophobicity observed in the salmon 
Fig. 1 Active and total sulfhydryl groups $\left(\mathrm{SH}_{2}\right)(\mathbf{a})$ and surface hydrophobicity (b) of fish proteins and the reference proteins
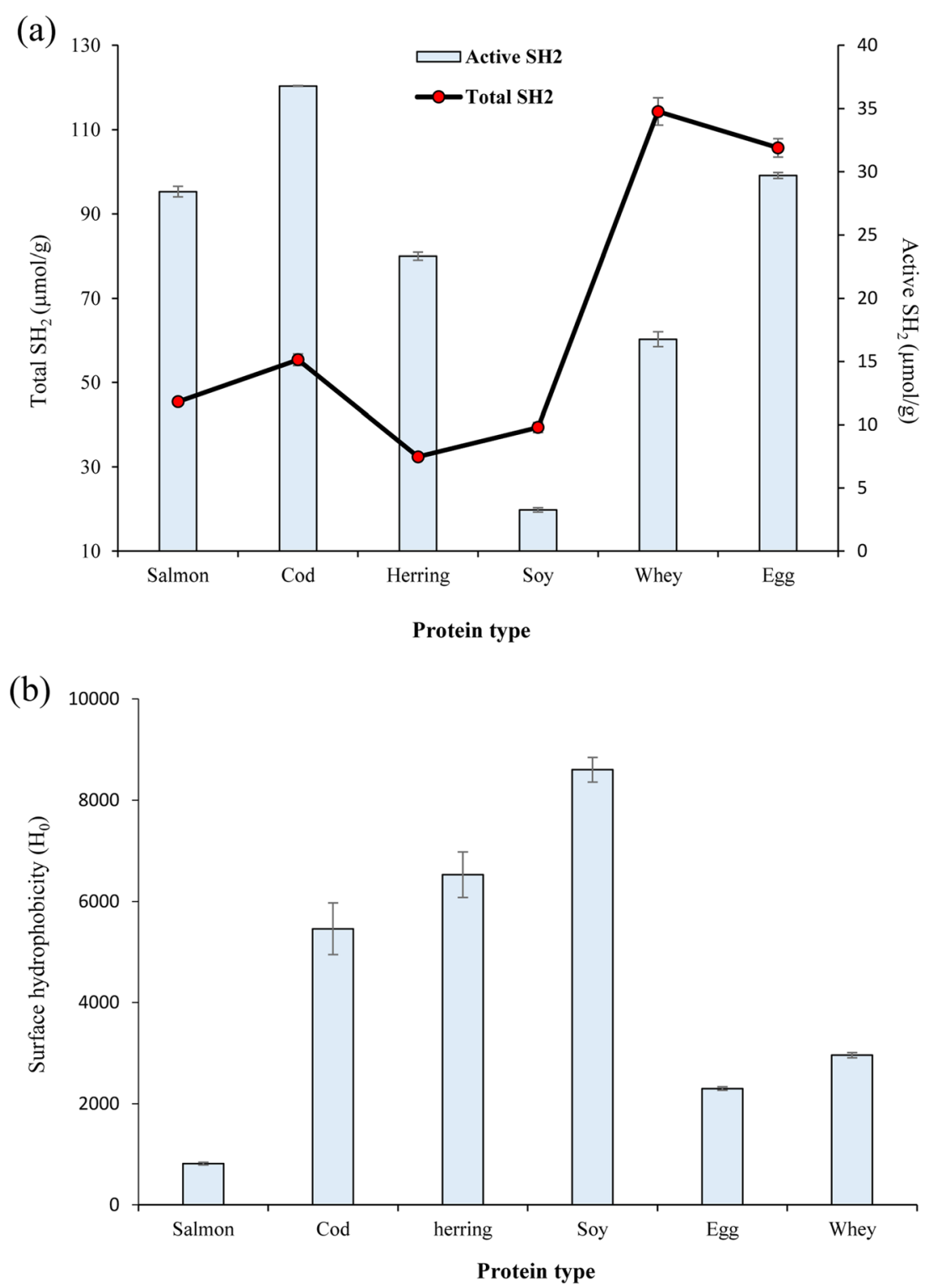

protein powder might be attributed to its higher refolding capacity after pH-readjustment. It might also be related to, e.g., hydrophobic aggregation of proteins to form more stable structure in salmon proteins after experiencing extreme pHs (Zhao et al. 2015). It has been also previously reported that too high protein denaturing factors like hydrostatic pressure in contrast with moderate pressures reduced surface hydrophobicity of proteins by causing hydrophobic interaction of the proteins (Qin et al. 2013). Surface hydrophobicity of all FPPs was lower than for SPI while herring and cod protein powders showed considerably higher surface hydrophobicity than EWP and WPI. Similarly, Pires et al. (2012) reported lower surface hydrophobicity in hake protein powder compared to SPI. The lower surface hydrophobicity measured for EWP and WPI might also be related to their different production and/or drying method.

\section{Color and bulk density}

Among the FPPs, the highest whiteness was measured in cod protein powder (71.83), which was significantly higher than the whiteness of salmon (66.09) and herring (54.75) protein powders $(p<0.05)$ (Table 2). Cod protein powder showed a light grey color while salmon and herring protein powders had brown and dark brown appearance, respectively. The whiteness values of the cod and salmon protein powders coincide with what was previously reported for powders made of Alaska pollock (64-76) (Sathivel and Bechtel 2006), but were lower than Cape hake protein powder (78) (Pires et al. 2012). The lowest amount of whiteness was measured in herring protein powder which is most likely related to the high amount of heme-pigment in the herring raw material and also the higher amount remaining in the herring protein isolate (data 
Table 2 Color of FPPs, soy protein isolate, egg white protein, whey protein isolate, and emulsions containing fish protein powders

\begin{tabular}{|c|c|c|c|c|c|c|}
\hline & & $L$ & $a$ & $b$ & Whiteness & Bulk density $(\mathrm{g} / \mathrm{ml})$ \\
\hline \multirow[t]{6}{*}{ Protein } & Salmon & $72.51 \pm 0.15^{\mathrm{e}}$ & $7.51 \pm 0.02^{\mathrm{a}}$ & $18.37 \pm 0.07^{\mathrm{b}}$ & $66.09 \pm 0.16^{\mathrm{e}}$ & $0.49 \pm 0.01^{\mathrm{c}}$ \\
\hline & Cod & $76.37 \pm 0.18^{\mathrm{d}}$ & $3.50 \pm 0.06^{\mathrm{c}}$ & $14.94 \pm 0.15^{\mathrm{c}}$ & $71.83 \pm 0.24^{\mathrm{d}}$ & $0.60 \pm 0.01^{\mathrm{a}}$ \\
\hline & Herring & $57.59 \pm 0.05^{\mathrm{f}}$ & $6.85 \pm 0.02^{\mathrm{b}}$ & $14.21 \pm 0.06^{\mathrm{d}}$ & $54.75 \pm 0.04^{\mathrm{f}}$ & $0.59 \pm 0.01^{\mathrm{a}}$ \\
\hline & Soy & $88.15 \pm 0.14^{\mathrm{c}}$ & $0.79 \pm 0.01^{\mathrm{d}}$ & $14.03 \pm 0.04^{\mathrm{e}}$ & $81.62 \pm 0.09^{\mathrm{b}}$ & $0.52 \pm 0.00^{\mathrm{b}}$ \\
\hline & Egg & $94.00 \pm 0.16^{\mathrm{a}}$ & $-2.43 \pm 0.02^{\mathrm{f}}$ & $18.94 \pm 0.07^{\mathrm{a}}$ & $79.98 \pm 0.10^{\mathrm{c}}$ & $0.60 \pm 0.01^{\mathrm{a}}$ \\
\hline & Whey & $92.70 \pm 0.09^{\mathrm{b}}$ & $-0.96 \pm 0.03^{\mathrm{e}}$ & $10.50 \pm 0.14^{\mathrm{f}}$ & $87.17 \pm 0.12^{\mathrm{a}}$ & $0.48 \pm 0.00^{\mathrm{c}}$ \\
\hline \multirow[t]{3}{*}{ Emulsion system } & Salmon & $83.91 \pm 0.13^{\mathrm{a}}$ & $-0.27 \pm 0.01^{\mathrm{a}}$ & $8.23 \pm 0.05^{\mathrm{b}}$ & $81.92 \pm 0.14^{\mathrm{a}}$ & - \\
\hline & Cod & $83.59 \pm 0.14^{\mathrm{a}}$ & $-0.53 \pm 0.01^{\mathrm{b}}$ & $8.10 \pm 0.04^{b}$ & $81.70 \pm 0.14^{\mathrm{a}}$ & - \\
\hline & Herring & $75.29 \pm 0.11^{\mathrm{b}}$ & $0.69 \pm 0.02^{\mathrm{c}}$ & $12.36 \pm 0.09^{\mathrm{a}}$ & $72.36 \pm 0.13^{\mathrm{b}}$ & - \\
\hline
\end{tabular}

Different small letters in each column show significant differences $(p \leq 0.05)$. pH 11.5-12.5 shows the used solubilization $\mathrm{pHs}$

not shown). These pigments can be oxidized during the precipitation at $\mathrm{pH} 5.5$ to yield the brown methemoglobin or metmyoglobin. In general, the used reference protein powders had higher whiteness than FPPs with maximum of 87.17 for WPI. The major differentiating color parameter between the FPPs and the reference proteins was redness (i.e., $a^{*}$ ). The FPPs showed redness values of 3.5 to 7.5 while it was $<0.8$ in the three reference proteins. This is most likely related to the heme proteins of the fish FPPs, as were discussed above for whiteness. The difficulty to completely remove heme pigments during the $\mathrm{pH}$-shift process has been shown earlier using $\mathrm{Hb}$ fortified cod mince (Abdollahi et al. 2016). Yellowness index (i.e., $b^{*}$ ) varied between 14.41 for the herring protein and 18.37 for the salmon protein.

Bulk density is a determinant factor in packaging requirements of protein powders. Bulk density of salmon protein powder $(0.49 \mathrm{~g} / \mathrm{ml})$ was significantly lower than cod $(0.60 \mathrm{~g} /$ $\mathrm{ml})$ and herring $(0.59 \mathrm{~g} / \mathrm{ml})$ protein powders $(p<0.05)$ (Table 2). It has been reported that bulk density depends on the combined effects of interrelated factors such as the intensity of attractive inter-particle forces, particle size, and number of contact points (Shao et al. 2014). The lower bulk density of salmon protein powder can be related to its lower protein content compared with cod and herring protein powders. The bulk density of the three FPPs was considerably lower than bulk density of FPP from saithe cut-offs $(3.7-4.7 \mathrm{~g} / \mathrm{ml})$, but were in the range of the bulk densities obtained for the reference proteins $(0.48-0.60 \mathrm{~g} / \mathrm{ml})$ used in this study.

\section{Solubility of proteins in water}

Solubility of protein powders in water at different $\mathrm{pHs}$ are summarized in Fig. 2a. FPPs and SPI showed a typical Ushaped solubility curve with minimum solubility measured at their isoelectric point. Solubility of FPPs at $\mathrm{pH} 7$ was 9$11 \%$, which was higher than what was reported for hake protein powder (4\%) (Pires et al. 2012) but lower than saithe protein isolate (Shaviklo et al., 2012) which can be related to different methods used for solubility measurement. By increasing solubilization $\mathrm{pH}$ to 10 , the solubility of salmon and cod protein increased up to 62 and 53\% which was considerably higher than herring protein solubility $(29 \%)$. All FPPs showed solubility $>95 \%$ at $\mathrm{pH} 12$ which was significantly $(p<0.05)$ higher than SPI solubility $(85 \%)$ at that $\mathrm{pH}$. In general, protein solubility of the FPPs showed similar pattern as non-processed fish myofibrillar proteins, which have high solubility at very alkaline and acidic pHs and very low solubility at $\sim \mathrm{pH} 5.5$. Denaturation occurring during the $\mathrm{pH}-$ shift process and being reflected in high surface hydrophobicity of the fish proteins might have affected solubility of the FPPs. However, compared to salmon (95\%) and herring ( $81 \%$ ), the cod protein powder showed considerably lower solubility at $\mathrm{pH} 2$ (50\%). EWP and WPI showed very high solubility $(>80 \%)$ at all studied pHs. Solubility of proteins in water depends on several factor including surface characteristics of their amino acids, molecular weight, and conformational situation (Timilsena et al. 2016). For example, whey proteins are low molecular weight globular proteins remaining after $\mathrm{pH}$-adjustment of milk to 4.6 during the casein coagulation process. That fish proteins showed almost similar or better solubility pattern compared to SPI can open up for similar application as SPI in food products.

\section{Emulsion activity and stability}

Emulsification capacity can define potentials of proteins for application in a wide range of emulsion-based food products. Emulsion activity index (EAI) and emulsion stability index (ESI) of FPPs and reference proteins as a function of different pHs are shown in Fig 2b, c. All protein powders except EWP showed their minimum EAI at $\mathrm{pH} 5$ which was around the isoelectric region and increased above and below this region. For fish and soy protein, this can be related to their minimum solubility between $\mathrm{pH} 4$ and 6 which was shown in Fig. 2a. At $\mathrm{pH} 7$ which was the initial $\mathrm{pH}$ of the FPPs, salmon protein powder $\left(30 \mathrm{~m}^{2} / \mathrm{g}\right)$ showed considerably lower EAI than cod 
Fig. 2 Water solubility (a), emulsion activity index (EAI) (b), and emulsion stability index (ESI) (c) of fish proteins and the reference proteins as a function of $\mathrm{pH}$.

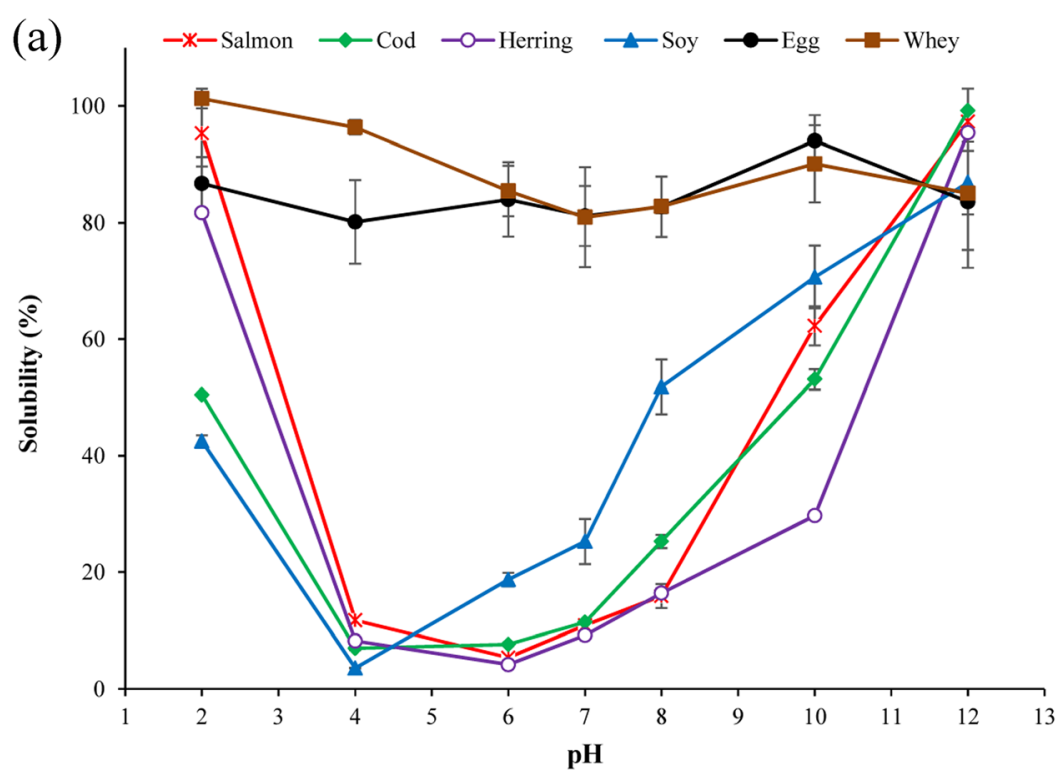

(b) $\quad-x-$ Salmon $\rightarrow-$ Cod $\multimap-$ Herring $\rightarrow$ Soy $\rightarrow$ Egg $\rightarrow-$ Whey
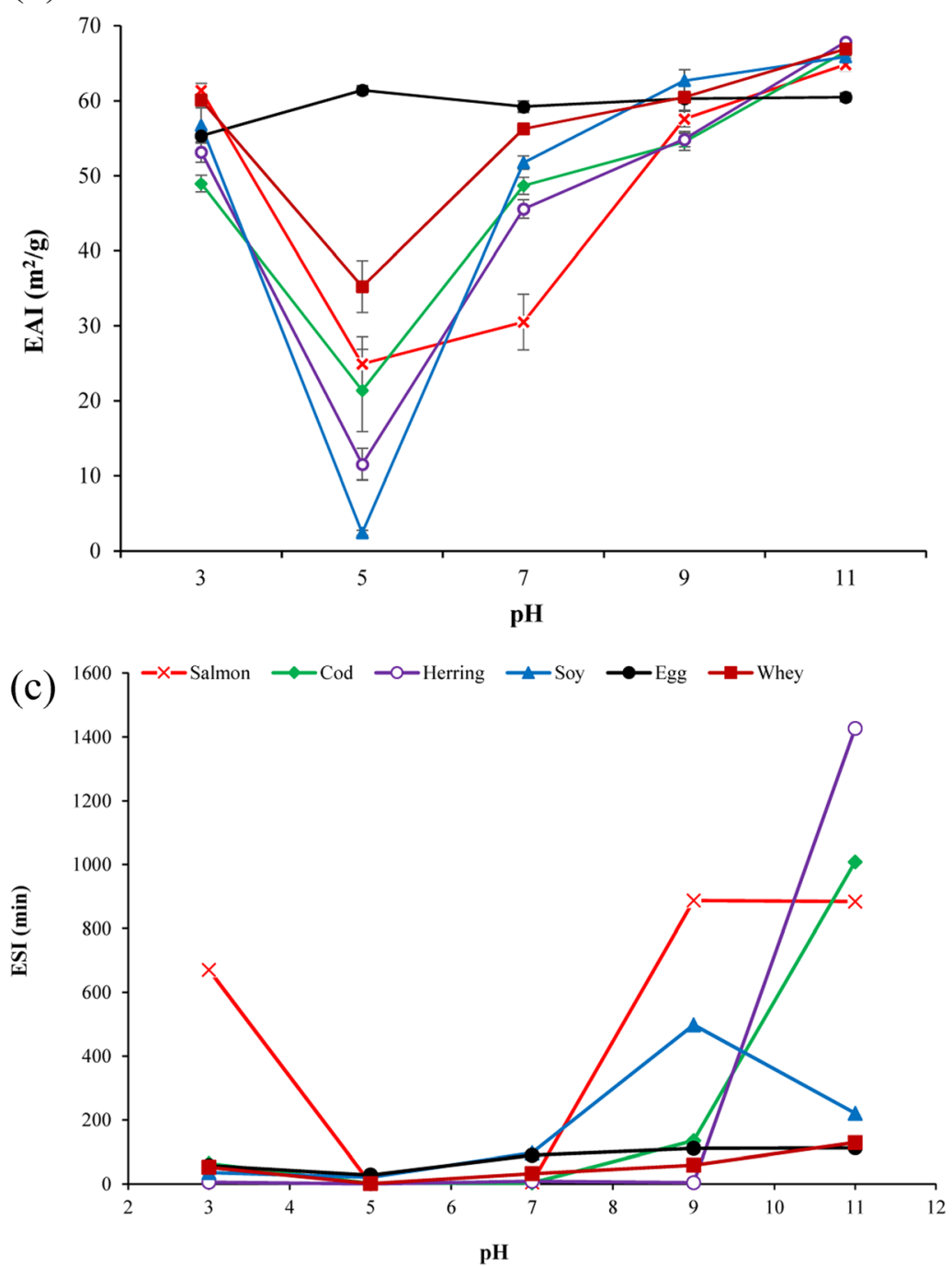
(48 $\mathrm{m}^{2} / \mathrm{g}$ ) and herring $\left(45 \mathrm{~m}^{2} / \mathrm{g}\right)$ samples which had EAI almost as good as SPI $\left(51 \mathrm{~m}^{2} / \mathrm{g}\right)$. EAI of FPPs produced in this study was higher than EAI reported for protein powder from Cape hake sawdust $\left(10 \mathrm{~m}^{2} / \mathrm{g}\right)$ produced using the $\mathrm{pH}$-shift method (Pires et al. 2012). Emulsion capacity of protein will depend on their ability to adsorb on the oil-water interface. Once absorbed, the emulsifying agent protects dispersed phase droplets from coalescence by forming a film at the oilwater interface and by reducing the interfacial tension (Phillips 1994). The initial absorption of proteins to the interface will be determined both by the proteins solubility that let protein reach to the interface and by its hydrophobicity to provide optimum contact of non-polar groups with the oil phase (Shevkani et al. 2015). Thus, the lower EAI of salmon protein powder can be related to its considerably lower surface hydrophobicity (Fig 1b). Similarly, Kristinsson and Hultin (2003) reported a very good relationship between increase in surface hydrophobicity and emulsion activity of $\mathrm{pH}$-shifttreated cod myosin. When further increasing $\mathrm{pH}$ to 9 and 11, the EAI of the FPPs increased $\left(64-67 \mathrm{~m}^{2} / \mathrm{g}\right)$ and reached its maximum at $\mathrm{pH} 11\left(>64 \mathrm{~m}^{2} / \mathrm{g}\right)$ which was even higher than EAI of EWP $\left(60 \mathrm{~m}^{2} / \mathrm{g}\right)$. This trend also coincides with the trend that was seen in the FPPs solubility (Fig. 2a). Maximum EAI was measured for herring protein powders $\left(67 \mathrm{~m}^{2} / \mathrm{g}\right)$ which was followed by cod $\left(66 \mathrm{~m}^{2} / \mathrm{g}\right)$ and salmon $\left(64 \mathrm{~m}^{2} / \mathrm{g}\right)$. On the acidic side ( $\left.\mathrm{pH} 2\right)$, however, salmon protein powder showed maximum EAI $\left(63 \mathrm{~m}^{2} / \mathrm{g}\right)$ which was followed by herring protein powder $\left(53 \mathrm{~m}^{2} / \mathrm{g}\right)$ and the minimum was measured for cod protein powder $(48 \%)$. This also correlated very well with the solubility of the FPPs and their hydrophobicity as shown previously. High emulsion capacity of FPPs might be related to the partial unfolding and denaturation of proteins experienced during the $\mathrm{pH}$-shift process which provides rapid adsorption of the relatively hydrophobic globular head of the $\mathrm{pH}$-treated protein to the nonpolar lipid globules (Panpipat and Chaijan 2017). We hypothesize that the process of conformational changes at the oil-water interface is due to loss in tertiary structure rather than secondary structure. This is because the interfacial energy at the oil-water interface is probably insufficient to overcome the activation energy barrier for complete unfolding of protein. The refolded proteins produced using the $\mathrm{pH}$-shift process would therefore be at an advantage over the native proteins, as they already have partly unfolded tertiary structure but a native secondary structure. For myosin, a very abundant protein of all the FPPs, this would mean that the head is in a molten globular state (Kristinsson and Hultin 2003). However, the FPPs developed in this study contained a mixture of myosin and other myofibrillar and sarcoplasmic proteins which can play role differently during emulsification process and should be considered.

ESI of the FPPs increased with increasing $\mathrm{pH}$ and was considerably higher than for all reference proteins at $\mathrm{pH} 11$. Salmon protein powder reached its maximum ESI at $\mathrm{pH} 9$ while herring showed maximum ESI at $\mathrm{pH} 11$, which was the only $\mathrm{pH}$ at which herring protein powder showed high ESI. In the acidic area, salmon protein showed a big difference in ESI compared with the other FPPs. As mentioned, overall emulsion capacity of proteins depends to their ability to adsorb to the oil-water interface, but the stability of the formed emulsion (i.e., ESI) will be determined by the properties of the formed layer (Shevkani et al. 2015). In this way, high percentage of active sulfhydryl groups measured in FPPs (Fig. 1a) might have facilitated formation of a stable interface film layer and helped ESI compared to other proteins.

\section{Dynamic rheology and color of emulsions containing fish proteins}

The results of frequency sweep tests of the emulsions, plotting storage modulus $\left(G^{\prime}\right)$ and loss modulus $\left(G^{\prime \prime}\right)$ against frequency are shown in Fig. 3a. In all samples, $G^{\prime}$ and $G^{\prime \prime}$ increased slightly with logaritmic increase of frequecy but $G^{\prime}$ was always higher than $\mathrm{G}^{\prime \prime}$ in all emulsions. It means that the emulsions had a structured system like a viscoelastic solid. Pires et al. (2012) also reported similar results for reological properties of emulsion prepared from Cape hake protein powder but they found lower $G^{\prime}$ for the emulsion compared to the emulsions prepared from cod and salmon proteins in this study. The emulsion prepared from cod protein powder showed the highest $G^{\prime}$ and $G^{\prime \prime}$ value indicating that it had more structured system compared with emulsions from salmon and herring protein powders (Tomé et al. 2014).

The ossilatory stress sweep test can provide information about the stability of the emulsion by increasing the amplitude of deformation or shear stress while the frequency is kept constant. As shown in Fig. 3b, the emulsion made with cod protein powder start to breakdown at $116 \mathrm{~Pa}$ which was follwed by those from salmon (81 $\mathrm{Pa}$ ) and herring (10 Pa) proteins. That means that the emulsions made with cod and salmon protein powders showed considerably higher stabity compared with those made with herring protein powder. In addition, the cod protein powder containing emulsion showed the best viscoelastic properties and stability when high stress was applied on its structure.

In order to evalute general flow behavior of the emulsions made of FPPs, their viscosity was mesured as a function of the shear rate and their so called flow curve was shown in Fig. 3c. All emulsions showed a typical shear-thinning behavior with an initial Newtonian region with constant viscosity occurring at low shear rates followed by a region with straight-line decrease of viscosity with increasing shear rate. Pires et al. (2012) and Tomé et al. (2014) reported similare flow curve with shear thinning behavior for emulsions made with Cape hake protein. The cod protein powder containing emulsion showed the highest viscosity in the plateau region followed by the salmon protein powder containing emulsion, while the 
Fig. 3 Frequency sweep (a), amplitude sweep (b), and flow curve (c) of emulsions made of salmon, cod, and herring proteins (a)

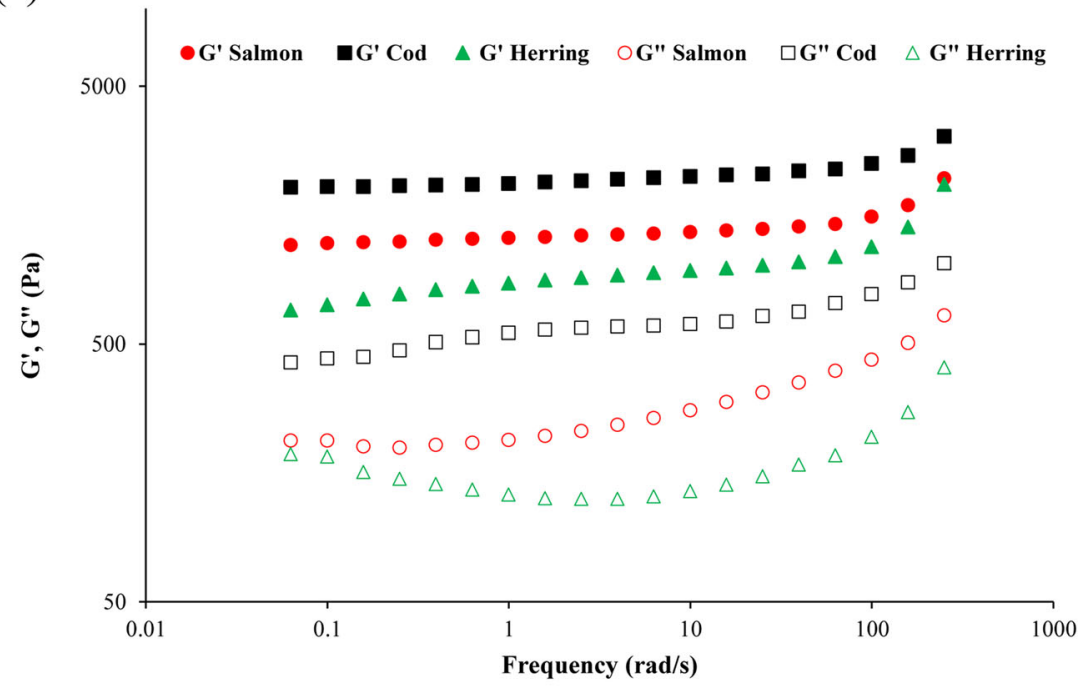

(b)

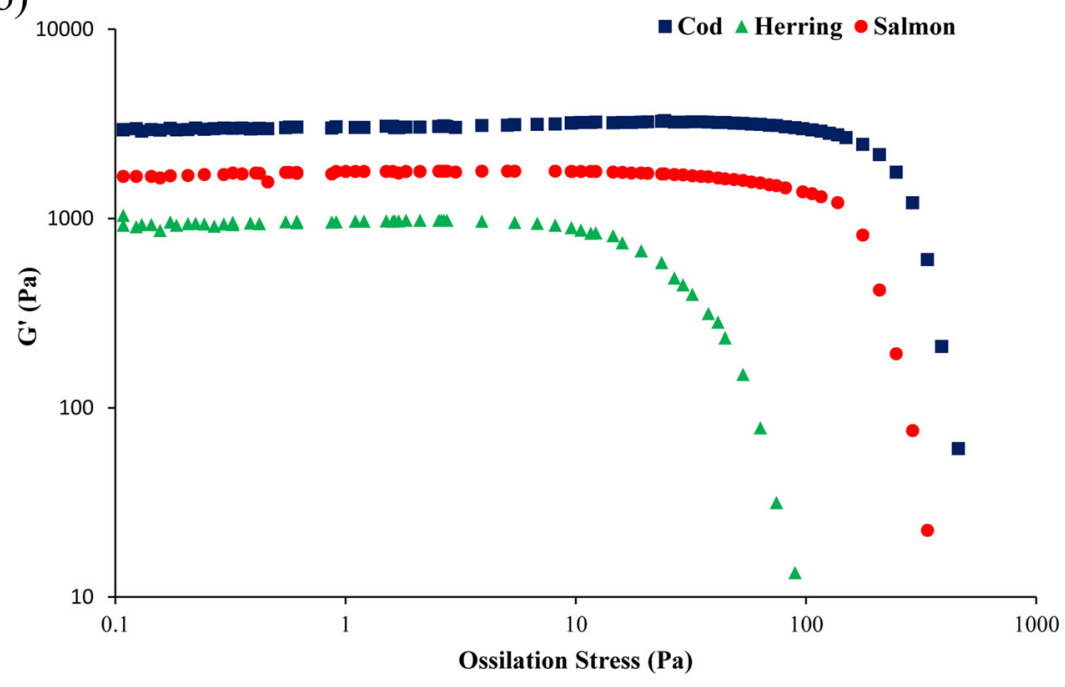

(c)

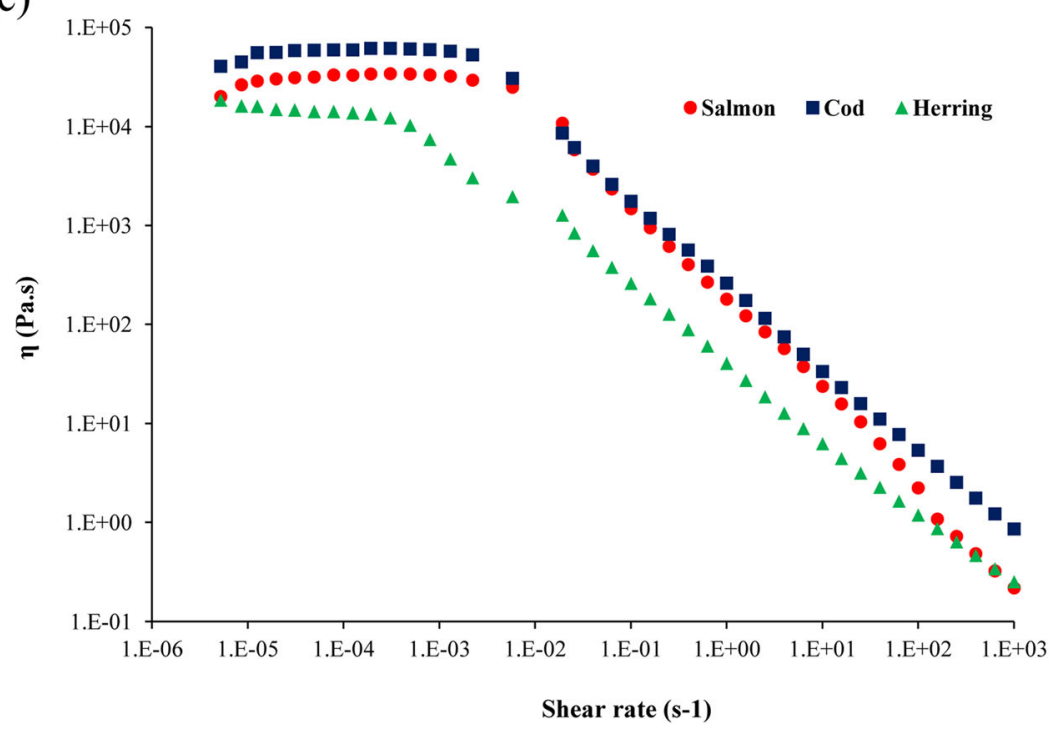


herring protein powder containg emulsion showed the lowest viscosity. The zero shear rate limiting viscosity $\left(\eta_{0}\right)$ rsulted from Carreau equation (Fig. 3c) showed a dependency to the origin of the used protein powder for emulsion preparation. Finally, cod protein powder resulted in the emulsion with the best viscoelastic properties, structure stability, and highest viscosity followed by salmon protein powder, while herring protein powder resulted the weakest emulsion. This can be related to the higher amount of myosin heavy chain with high molecular weight detected in cod protein powders which play critical role in emulsion capacity of myofibrillar proteins as discussed before (Fig. 5b). As stated earlier, it has been reported that higher molecular weight proteins and high soluble protein content can improve interactions between droplets in an emulsion (Yin et al. 2011). This is also in agreement with its higher content of active sulfhydryl groups and high surface hydrophobicity.

Color attributes of the emulsions made of cod and salmon protein powders (Table 2) showed high whiteness which shows high potential of these two powders for application in emulsion-type products. However, herring protein powder affected the whiteness negatively due to its dark brown color.

\section{Foaming properties}

Foaming capacity (FC) and foam stability (FS) can clarify potential of proteins for application in certain food systems, where aeration and overrun is needed, e.g., whipped toppings, baked foods, and ice-cream mixes (Shevkani et al. 2015). FC and FS of FPPs and the reference proteins as a function of $\mathrm{pH}$ are summarized in Fig. 4a, b. FC of the FPPs showed a pHdependent behavior with a minimum within the isoelectric point region. FC of all FPPs increased by going far away from their isoelectric point region towards the acidic and alkaline side, but it was significantly higher at alkaline $\mathrm{pHs}$ than acid ones $(p<0.05)$. At $\mathrm{pH} 7$, cod protein showed the highest FC $(65 \%)$ followed by salmon $(53 \%)$ and herring (48\%) protein powders which were significantly lower than FC of EWP and SPI $(81 \%)(p<0.05)$. However, cod and herring protein powders showed FC (113 and 130\%, respectively) higher than EWP (85\%) and SPI (105\%) at pH 11 but still lower than WPI (160\%). Foam formation includes two main steps: (1) diffusion of solubilized proteins and adsorption to the gasliquid interface to reduce surface tension and (2) protein unfolding and orientation of hydrophobic regions to the gas phase and hydrophilic regions to the liquid phase to assume train and loop formations (Lam et al. 2016). In this way, small flexible proteins like whey and egg with high solubility can reduce surface tension very quickly and make foam. Thus, the higher foaming capacity of FPPs at higher pHs can be related to the increase in their solubility that let them migrate quickly to the air/liquid interface and form the protective membrane (Shevkani et al. 2015). Also, the higher FC of cod and herring protein powder at $\mathrm{pH} 11$ compared to SPI and EWP might be also related to their relatively higher solubility, protein content, and surface hydrophobicity at this $\mathrm{pH}$ as shown previously. It is hypothesized that protein conformational changes occurring during the $\mathrm{pH}$-shift process, which increase their surface hydrophobicity, could also help them to unfold and orient their hydrophobic regions to the gas phase and hydrophilic regions to the liquid phase more quickly when they are solubilized enough. The lower FC of salmon protein isolate at $\mathrm{pH} 11$, despite its high solubility at this $\mathrm{pH}$, also coincide with its considerably lower surface hydrophobicity and its lower protein content compared to cod and herring proteins.

At all studied pHs, FPPs showed very high (>95\%) foam stability which was as good as SPI but significantly higher than WPI and EWP $(p<0.05)$. In general, stability of foams depends on the stability of the protein film formed in the gasliquid interfacial layer and its gas permeability (Barać et al. 2011). Better foam stabilizers should be able to form greater protein-protein interactions that will increases viscosity and facilitate formation of a multilayer cohesive protein film at the interface (Panpipat and Chaijan 2017). It seems that the higher molecular weight fish protein aggregates have been able to form a thicker, more cohesive and viscoelastic film around each gas bubble (Qin et al. 2013), thus showing very high foam stability compared with the reference proteins.

\section{Molecular structure and polypeptide pattern of protein powders}

FTIR spectra of protein powders from different origins are shown in Fig. 5a. All protein powders showed distinctive absorption bands at 3276-3282 $\mathrm{cm}^{-1}$ (Amide A, N-H, or O$\mathrm{H}$ stretching), 1631-1637 $\mathrm{cm}^{-1}$ (Amide $\mathrm{I}, \mathrm{C}=\mathrm{O}$, and $\mathrm{C}=\mathrm{N}$ stretching), 1515-1517 $\mathrm{cm}^{-1}$ (Amide II, C-N stretching, and $\mathrm{N}-\mathrm{H}$ bending), and 1232-12366 $\mathrm{cm}^{-1}$ (Amide III, PK6) (Ma et al. 2012; Chen et al. 2014). Among these peaks, the amide I absorption zone between 1600 and $1700 \mathrm{~cm}^{-1}$ can be useful to evaluate the secondary structure of proteins as it is the sum of overlapping component bands: $\alpha$-helix, $\beta$-sheet, and $\beta$-turn and random coils (Carbonaro and Nucara 2010). In herring protein powder, the peak related to Amide I shifted to lower wavenumber $\left(1633 \mathrm{~cm}^{-1}\right)$ compared to the corresponding peak from salmon and cod protein powders $\left(1637 \mathrm{~cm}^{-1}\right)$. Furthermore, in herring protein powder, the peak related to Amide A shifted to lower wavenumber $\left(3280 \mathrm{~cm}^{-1}\right)$ compared with salmon and cod protein powders $\left(3282 \mathrm{~cm}^{-1}\right)$. This might imply reduction in $\alpha$-helix structure of myosin in herring protein powder (Carbonaro and Nucara 2010). Raghavan and Kristinsson (2008) also reported that the $\mathrm{pH}$-shift process affected the secondary structure of catfish myosin and caused an increase in its $\beta$-sheet structure. These two peaks were also found in lower wavenumber in SPI, EWP, and WPI. These results may imply differences in the relative proportion of 
Fig. 4 Foaming capacity (a) and foaming stability (b) of FPPs and the reference proteins as a function of $\mathrm{pH}$

\section{(a)}

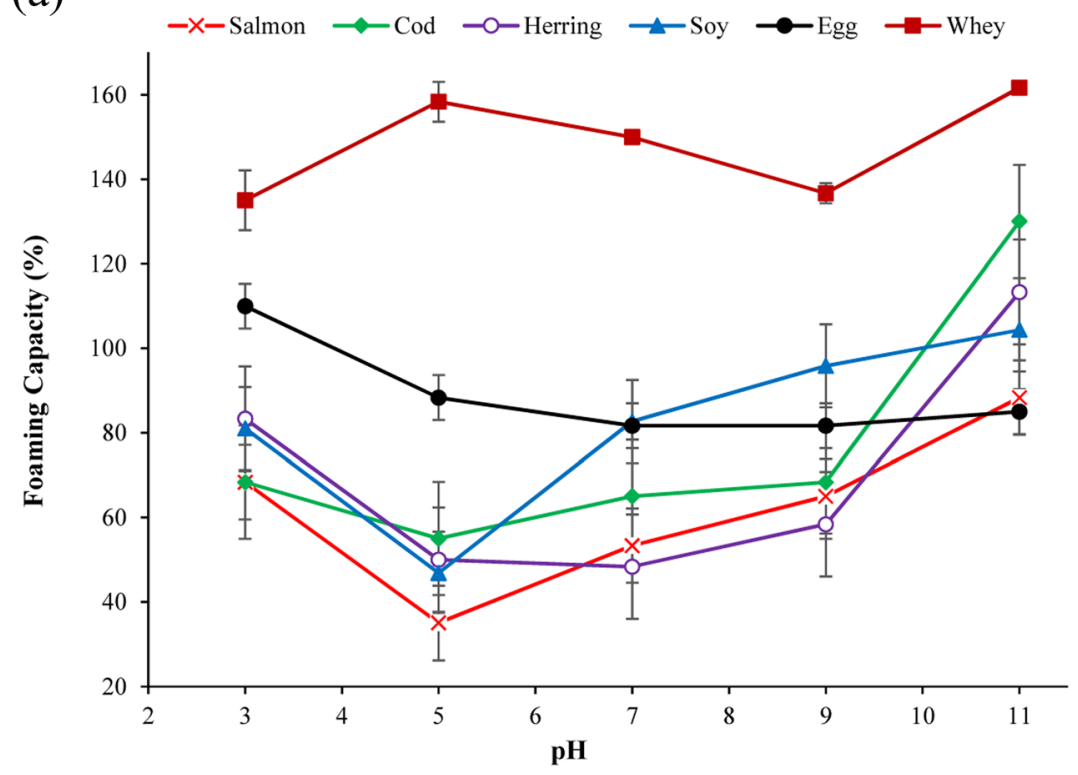

(b)

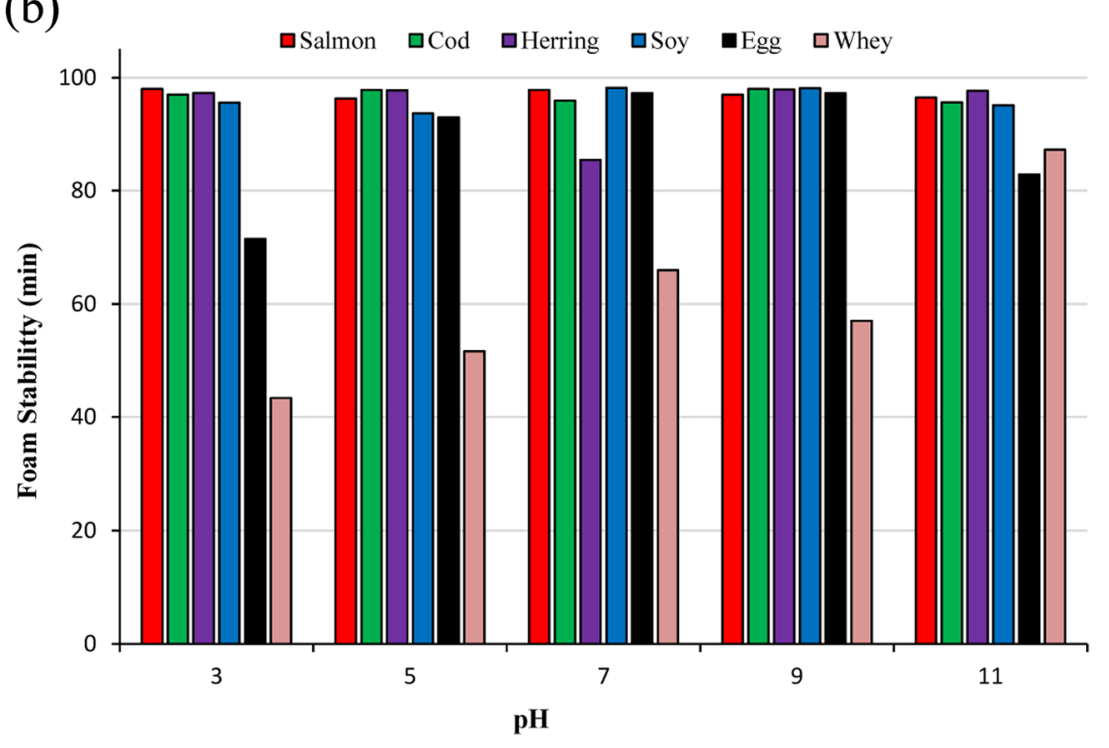

different secondary structure in the FPPs and the reference proteins. It has been shown that in general, globular proteins have higher proportion of $\alpha$-helix than $\beta$-sheet (Timilsena et al. 2016). In addition, in salmon and herring protein powders, a peak was seen at 1745 which was not detectable in other protein powders which could be related to ester bonds between glycerol and fatty acids of lipids (Van der Weerd et al. 2005).

Polypeptide pattern of FPPs and reference proteins are shown in Fig. 5b. With salmon and cod protein powders, myosin heavy chain (MHC) $(\sim 205 \mathrm{kDa})$ was the most abundant polypeptide followed by actin $(\sim 42 \mathrm{kDa})$. A dark shadow below the MHC in FPPs of all the three resources is also seen, which is not detectable in the polypeptide pattern of their raw materials. This might reflect slight proteolysis during the $\mathrm{pH}-$ shift process caused by enzyme activity (Yongsawatdigul and
Park 2004), an effect not frequently reported during alkaliaided $\mathrm{pH}$-shift processing of fish. Rather, proteolysis has been seen during acid-aided processing (Undeland et al. 2002). The maximum intensity of $\mathrm{MHC}$ was seen in cod protein isolate recovered at $\mathrm{pH}$ 11.5. Since MHC plays a well-known instrumental role in the functional properties of muscle protein (Kristinsson and Hultin 2003), this may explain the higher emulsion and foaming properties observed for the cod protein powders. Herring protein isolates showed considerably lower MHC band intensity which may also explain its poor functional properties. This low MHC content might be attributed to a high degree of hydrolysis occurring in the herring raw material already before the $\mathrm{pH}$-shift process due to the wellknown high proteolytic enzyme activity in the dark muscle species. 
Fig. 5 FTIR spectra (a) and polypeptide pattern (b) of FPPs and the reference proteins (a)

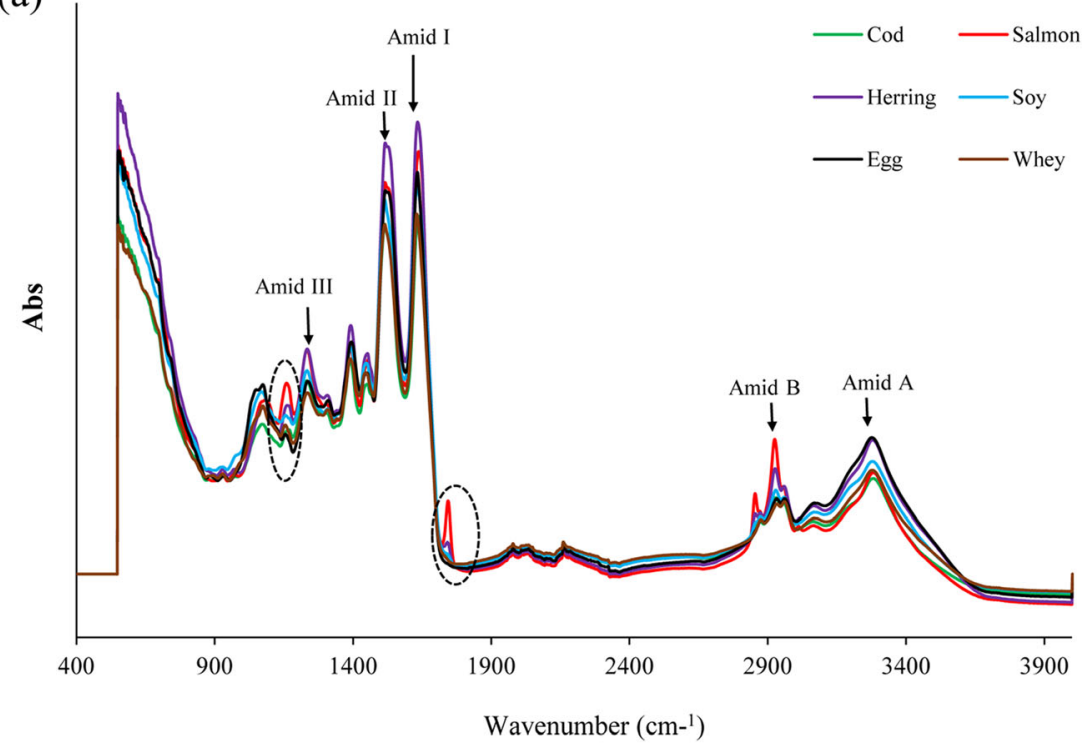

(b)

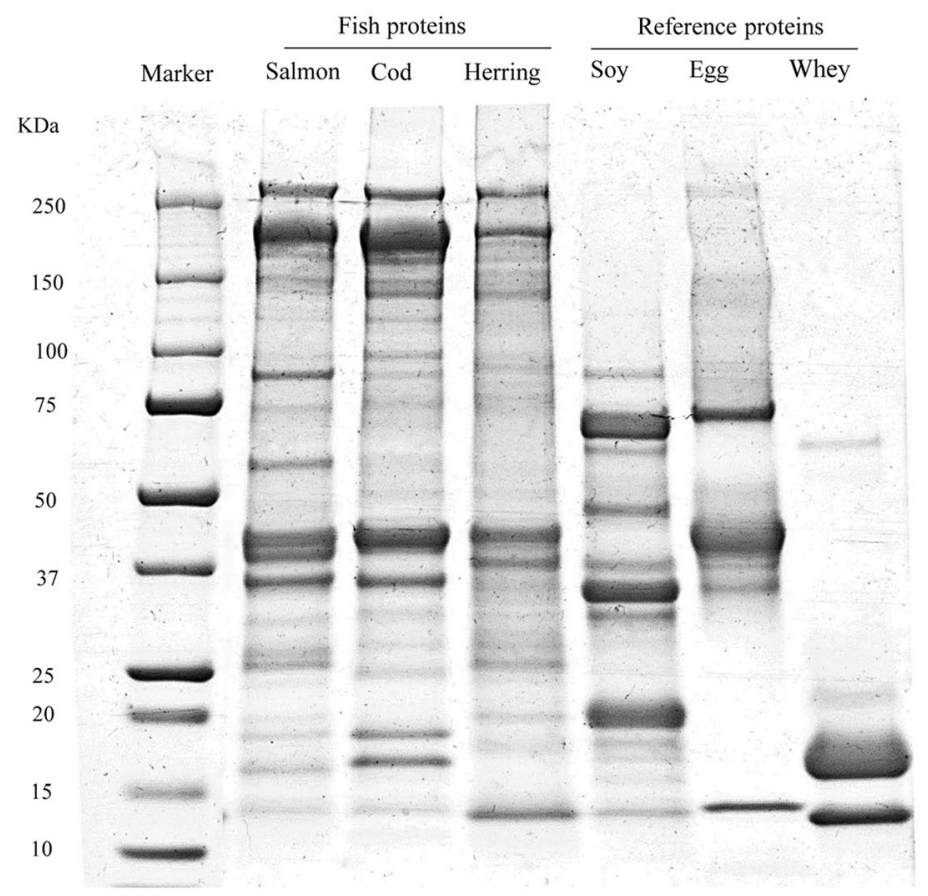

As can be seen, WPI contained two major bands including $\beta$-lactoglobulin $(\sim 18 \mathrm{kDa})$ followed by $\alpha$-lactoglobulin $(14 \mathrm{kDa})$ and a slight band reflecting bovine serum albumin $(\sim 66 \mathrm{kDa})$. EWP showed a major band at around $45 \mathrm{kDa}$ related to ovalbumin and another heavier band with less intensity at $\sim 76 \mathrm{kDa}$ related to ovotransferrin and a small band at around $14 \mathrm{kDa}$ which could be related to lysozyme. SPI showed also a mixture of polypeptides with molecular weights less than $75 \mathrm{kDa}$ including $\beta$-conglycinin fraction $(\alpha$ of 68 $\mathrm{kDa}, \alpha^{\prime}$ of $72 \mathrm{kDa}$, and $\beta$ of $52 \mathrm{kDa}$ polypeptides) and the acid and basic polypeptide chains of glycinin (A of $\sim 35 \mathrm{kDa}$, and
B of $\sim 20 \mathrm{kDa}$ ) (Nielsen 1985). The most noticeable difference between FPPs and reference proteins was the high number of band above $70 \mathrm{kDa}$ which was found in fish proteins but was not seen in soy, egg white, or whey protein. This difference in molecular weight distribution may explain differences observed in emulsion and foaming capacity of the proteins. Normally, smaller proteins with lower molecular weight can migrate more quickly to the interfacial layer of oil/water or air/ water to form a protective membrane. However, this property does not mean that such a protein can form stable emulsion or foam. 
Fig. 6 Sensorial attributes $(\mathrm{F}$ flavor, O odor) of fish proteins powders and soy protein isolate in scale from 0 to 100 evaluated by skilled panelists.

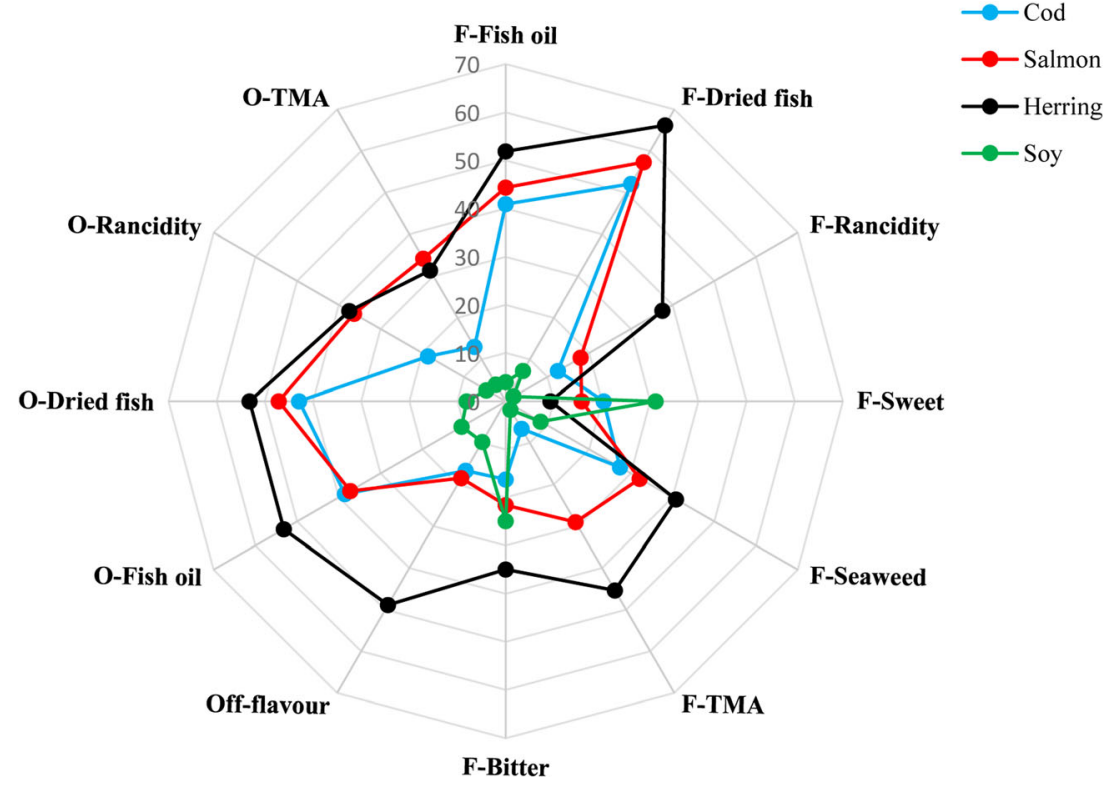

\section{Conclusions}

Functional and sensorial properties of the FPPs were strongly dependent on the origin of the used raw materials. The FPPs contained 404-499 mg essential amino acids per gram of protein, which was higher than their initial raw material and SPI. Cod and herring protein powders showed higher proportion of active sulfhydryl groups and surface hydrophobicity compared to WPI and EWP, which is affecting the functional properties of the FPPs. Emulsion and foaming capacities of the FPPs were related to their solubility and their origin and were as good as for EWP and SPI at high pHs. Cod protein powder showed better emulsion and foaming capacity than salmon and cod protein powders which was in line with its high active sulfhydryl group content, surface hydrophobicity, and myosin heavy chain content. Emulsion system developed from cod, and salmon protein powders showed substantially better viscoelastic properties, with higher stability and viscosity and whiteness, compared to herring protein powders. Sensorial properties of the FPPs were also dependent on their origin. Cod protein powder obtained the best sensory score while herring protein powder showed high levels of fish and lipid oxidation-related flavor and odor. Overall, it seems that the recoevered FPPs from filleting by-products using the $\mathrm{pH}-$ shift process have potential to be used as food ingredients, but their application will be goverenced by their origin and sensorial properties.

Acknowledgements The authors are grateful to Engelhardt Company for kindly providing the reference proteins and collaboration in the sensory test as well as Fisk Idag AB and the Scandic Pelagic Ellös AB for kindly providing the fish processing by-products. The authors also would like to thank Prof. Johan Bergenholtz for his kind help in rheological studies. tion of the powders. 
Funding Information The research was financially supported by Vinnova (project no. 2014-03469).

Open Access This article is distributed under the terms of the Creative Commons Attribution 4.0 International License (http:// creativecommons.org/licenses/by/4.0/), which permits unrestricted use, distribution, and reproduction in any medium, provided you give appropriate credit to the original author(s) and the source, provide a link to the Creative Commons license, and indicate if changes were made.

\section{References}

Abdollahi, M., Marmon, S., Chaijan, M., \& Undeland, I. (2016). Tuning the $\mathrm{pH}$-shift protein-isolation method for maximum hemoglobinremoval from blood rich fish muscle. Food Chemistry, 212, 213224. https://doi.org/10.1016/j.foodchem.2016.05.165.

Abdollahi, M., Rezaei, M., Jafarpour, A., \& Undeland, I. (2017). Dynamic rheological, microstructural and physicochemical properties of blend fish protein recovered from kilka (Clupeonella cultriventris) and silver carp (Hypophthalmichthys molitrix) by the $\mathrm{pH}$-shift process or washing-based technology. Food Chemistry, 229, 695-709. https://doi.org/10.1016/j.foodchem.2017.02.133.

Aspevik, T., Totland, C., Lea, P., \& Oterhals, Å. (2016). Sensory and surface-active properties of protein hydrolysates based on Atlantic salmon (Salmo salar) by-products. Process Biochemistry, 51(8), 1006-1014. https://doi.org/10.1016/j.procbio.2016.04.015.

Barać, M., Cabrilo, S., Pešić, M., Stanojević, S., Pavlićević, M., Maćej, O., \& Ristić, N. (2011). Functional properties of pea (Pisum sativum, L.) protein isolates modified with chymosin. International journal of molecular sciences, 12(12), 8372-8387. https://doi.org/10.3390/ijms12128372.

Carbonaro, M., \& Nucara, A. (2010). Secondary structure of food proteins by Fourier transform spectroscopy in the mid-infrared region. Amino Acids, 38(3), 679-690. https://doi.org/10.1007/s00726-0090274-3.

Chen, X., Chen, C. g., Zhou, Y. z., Li, P. j., Ma, F., Nishiumi, T., \& Suzuki, A. (2014). Effects of high pressure processing on the thermal gelling properties of chicken breast myosin containing K-carrageenan. Food Hydrocolloids, 40, 262-272. https://doi.org/10.1016/ j.foodhyd.2014.03.018.

Chen, Y.-C., \& Jaczynski, J. (2007). Protein recovery from rainbow trout (Oncorhynchus mykiss) processing byproducts via isoelectric solubilization/precipitation and its gelation properties as affected by functional additives. Journal of agricultural and food chemistry, 55(22), 9079-9088. https://doi.org/10.1021/jf071992w.

Chen, Y.-C., Tou, J. C., \& Jaczynski, J. (2007). Amino acid, fatty acid, and mineral profiles of materials recovered from rainbow trout (Oncorhynchus mykiss) processing by-products using isoelectric solubilization/precipitation. Journal of food science, 72(9), C527C535. https://doi.org/10.1111/j.1750-3841.2007.00522.x.

Gong, K. J., Shi, A. M., Liu, H. Z., Liu, L., Hu, H., Adhikari, B., \& Wang, Q. (2015). Emulsifying properties and structure changes of spray and freeze-dried peanut protein isolate. Journal of Food Engineering, 170, 33-40. https://doi.org/10.1016/j.jfoodeng.2015. 09.011

Hultin, H. O., Kelleher, S. D., Feng, Y., Richards, M. P., Kristinsson, H., Undeland, I., \& Ke, S. (2001). High efficiency protein extraction. Google Patents.

Kristinsson, H. G., \& Hultin, H. O. (2003). Effect of low and high pH treatment on the functional properties of cod muscle proteins. Journal of Agricultural and Food Chemistry, 51(17), 5103-5110.
Laemmli, U. K. (1970). Cleavage of structural proteins during the assembly of the head of bacteriophage T4. Nature, 227, 680-685.

Lam, A. C. Y., Can Karaca, A., Tyler, R. T., \& Nickerson, M. T. (2016). Pea protein isolates: structure, extraction, and functionality. Food Reviews International, 00(00), 1-22. https://doi.org/10.1080/ 87559129.2016.1242135.

Ma, F., Chen, C., Sun, G., Wang, W., Fang, H., \& Han, Z. (2012). Effects of high pressure and $\mathrm{CaCl} 2$ on properties of salt-soluble meat protein gels containing locust bean gum. Innovative Food Science and Emerging Technologies, 14, 31-37. https://doi.org/10.1016/j.ifset. 2011.12.001.

Markwell, M. A., Haas, S. M., Bieber, L. L., \& Tolbert, N. E. (1978). A modification of the Lowry procedure to simplify protein determination in membrane and lipoprotein samples. Analytical biochemistry, 87, 206-210. https://doi.org/10.1016/0003-2697(78)90586-9.

Marmon, S. K., \& Undeland, I. (2010). Protein isolation from gutted herring (Clupea harengus) using $\mathrm{pH}$-shift processes. Journal of agricultural and food chemistry, 58(19), 10480-10486. https://doi.org/ 10.1021/jf101057q.

Nielsen, N. C. (1985). Structure of soy proteins. New protein foods (USA).

Ogunwolu, S. O., Henshaw, F. O., Mock, H. P., Santros, A., \& Awonorin, S. O. (2009). Functional properties of protein concentrates and isolates produced from cashew (Anacardium occidentale L.) nut. Food Chemistry, 115(3), 852-858. https://doi.org/10.1016/j.foodchem. 2009.01.011.

Özcan, S., \& Șenyuva, H. Z. (2006). Improved and simplified liquid chromatography/atmospheric pressure chemical ionization mass spectrometry method for the analysis of underivatized free amino acids in various foods. Journal of Chromatography A, 1135(2), 179185. https://doi.org/10.1016/j.chroma.2006.09.039.

Panpipat, W., \& Chaijan, M. (2017). Functional properties of pH-shifted protein isolates from bigeye snapper ( Priacanthus tayenus ) head by-product. International Journal of Food Properties, 20(3), 596610. https://doi.org/10.1080/10942912.2016.1171778.

Phillips, L. G. (1994). Structure-function properties of food proteins. Academic Press.

Pires, C., Batista, I., Fradinho, P., \& Costa, S. (2009). Utilization of alkaline-recovered proteins from cape hake by-products in the preparation of frankfurter-type fish sausages. Journal of Aquatic Food Product Technology, 18(1-2), 170-190. https://doi.org/10.1080/ 10498850802629135 .

Pires, C., Costa, S., Batista, A. P., Nunes, M. C., Raymundo, A., \& Batista, I. (2012). Properties of protein powder prepared from Cape hake by-products. Journal of Food Engineering, 108(2), 268-275. https://doi.org/10.1016/j.jfoodeng.2011.08.020.

Qin, Z., Guo, X., Lin, Y., Chen, J., Liao, X., Hu, X., \& Wu, J. (2013). Effects of high hydrostatic pressure on physicochemical and functional properties of walnut (juglans regia 1.) protein isolate. Journal of the Science of Food and Agriculture, 93(5), 1105-1111. https:// doi.org/10.1002/jsfa.5857.

Raghavan, S. \& Kristinsson, H.G. (2008). Conformational and rheological changes in catfish myosin during alkali-induced unfolding and refolding. Food Chemistry, 107, 385-398.

Raghavan, S., \& Hultin, H. O. (2009). Effect of various antioxidants on the oxidative stability of acid and alkali solubilized muscle protein isolates. Journal of Food Biochemistry, 33(2), 163-175. https://doi. org/10.1111/j.1745-4514.2008.00202.x.

Santana, P., Huda, N., \& Yang, T. A. (2012). Technology for production of surimi powder and potential of applications. International Food Research Journal, 19(4), 1313-1323. https://doi.org/10.1016/ S0268-005X(03)00082-1.

Sathivel, S., \& Bechtel, P. J. (2006). Properties of soluble protein powders from Alaska pollock (Theragra chalcogramma). International Journal of Food Science and Technology, 41(5), 520-529. https:// doi.org/10.1111/j.1365-2621.2005.01101.x. 
Sathivel, S., Bechtel, P. J., Babbitt, J., Prinyawiwatkul, W., Negulescu, I. I., \& Reppond, K. D. (2004). Properties of protein powders from arrowtooth flounder (Atheresthes stomias) and herring (Clupea harengus) byproducts. Journal of Agricultural and Food Chemistry, 52, 5040-5046. https://doi.org/10.1021/jf0351422.

Shahidi, F. (2006). Maximising the value of marine by-products. Woodhead Publishing.

Shao, D., Atungulu, G. G., Pan, Z., Yue, T., Zhang, A., \& Fan, Z. (2014). Characteristics of isolation and functionality of protein from tomato pomace produced with different industrial processing methods. Food and Bioprocess Technology, 7(2), 532-541. https://doi.org/ 10.1007/s11947-013-1057-0.

Shaviklo, G. R., Thorkelsson, G., Arason, S., \& Sveinsdottir, K. (2012). Characteristics of freeze-dried fish protein isolated from saithe (Pollachius virens). Journal of food science and technology, 49(3), 309-318. https://doi.org/10.1007/s13197-011-0285-4.

Shevkani, K., Singh, N., Kaur, A., \& Rana, J. C. (2015). Structural and functional characterization of kidney bean and field pea protein isolates: a comparative study. Food Hydrocolloids, 43, 679-689. https://doi.org/10.1016/j.foodhyd.2014.07.024.

Taskaya, L., Chen, Y.-C., \& Jaczynski, J. (2009). Functional properties of proteins recovered from silver carp (Hypophthalmichthys molitrix) by isoelectric solubilization/precipitation. LWT - Food Science and Technology, 42(6), 1082-1089. https://doi.org/10.1016/j.lwt.2009. 02.007 .

Timilsena, Y. P., Adhikari, R., Barrow, C. J., \& Adhikari, B. (2016). Physicochemical and functional properties of protein isolate produced from Australian chia seeds. Food Chemistry, 212, 648-656. https://doi.org/10.1016/j.foodchem.2016.06.017.

Tomé, A. S., Pires, C., Batista, I., Sousa, I., \& Raymundo, A. (2014). Protein gels and emulsions from mixtures of Cape hake and pea proteins. Journal of the Science of Food and Agriculture, (April). doi: $10.1002 /$ jsfa.6717
Undeland, I., Hall, G., Wendin, K., Gangby, I., \& Rutgersson, A. (2005). Preventing lipid oxidation during recovery of functional proteins from herring (Clupea harengus) fillets by an acid solubilization process. Journal of Agricultural and Food Chemistry, 53(14), 56255634. https://doi.org/10.1021/jf0404445.

Undeland, I., Kelleher, S., \& Hultin, H. (2002). Recovery of functional proteins from herring (Clupea harengus) light muscle by an acid or alkaline solubilization process. Journal of agricultural and ..., 7371-7379. http://pubs.acs.org/doi/abs/10.1021/jf020199u. Accessed 3 January 2015.

Van der Weerd, J., Van Loon, A., \& Boon, J. (2005). FTIR studies of the effects of pigments on the aging of oil. Studies in Conservation, 50(JANUARY), 3-22. https://doi.org/10.2307/25487713.

WHO/FAO/UNU. (2007). Protein and amino acid requirements in human nutrition. World Health Organization technical report series, (935), 1-265. doi:ISBN 9241209356.

Yin, H., Wan, Y., Pu, J., Bechtel, P. J., \& Sathivel, S. (2011). Functional properties of protein fractions of channel catfish (Ictalurus punctatus) and their effects in an emulsion system. Journal of Food Science, 76(3). doi: 10.1111/j.1750-3841.2011.02057.x

Yongsawatdigul, J., \& Park, J. W. (2004). Effects of alkali and acid solubilization on gelation characteristics of rockfish muscle proteins. Journal of Food Science, 69(7), 499-505. https://doi.org/10.1111/j. 1365-2621.2004.tb13642.x.

Zhao, J., Dong, F., Li, Y., Kong, B., \& Liu, Q. (2015). Effect of freezethaw cycles on the emulsion activity and structural characteristics of soy protein isolate. Process Biochemistry, 50(10), 1607-1613. https://doi.org/10.1016/j.procbio.2015.06.021.

Zhong, S., Liu, S., Cao, J., Chen, S., Wang, W., \& Qin, X. (2016). Fish protein isolates recovered from silver carp (Hypophthalmichthys molitrix) by-products using alkaline $\mathrm{pH}$ solubilization and precipitation. Journal of Aquatic Food Product Technology, 25(3), 400413. 